Published in AJSE, Vol:17, Issue: 03

Received on $13^{\text {th }}$ September 2018

Revised on $19^{\text {th }}$ October 2018

Accepted on $30^{\text {th }}$ October 2018

\title{
Comparative Study of Thyristor vs IGBT Based AC-DC Power Converter
}

\author{
Md. Saiful Islam, Md. Rifat-Ul-Karim Shovon, Mohammad Abdul Goffar Khan
}

\begin{abstract}
This paper presents a comparative study of the application of Thyristor versus IGBT in AC-DC controlled power converter. Both simulation and practical experiment have been carried out to test the relationship between the average output voltage $\left(V_{d c}\right)$ with firing angle $(\alpha$, for Thyristor) and triggering pulse width ( $\delta$, for IGBT). Also the total harmonic distortion (THD) has been observed in both the cases. It is observed that IGBT based power converter introduces more harmonics in the system, in spite of more symmetrical output voltage wave shape.
\end{abstract}

Keywords- AC-DC converter, firing pulse, micro-controller, MATLAB/Simulink, Total Harmonic Distortion (THD)

\section{INTRODUCTION}

The demand for control of electric power for electric motor drive systems and industrial controls existed for many years, and this lead to early development of the Ward-Leonard system to obtain a variable dc voltage for the control of dc motor drives [1]-[4]. Different types of power converter contribute to control the electric power from one form to another. Among these converters AC-DC converter or rectifier [5]-[11] is the one which control the $\mathrm{AC}$ power as input and produces constant DC in the output. Modern power converters use power electronics devices which are primarily based on the switching of the power semiconductor devices [12]. The development of microprocessors [13]-[15] and microcomputer technology has a great impact on the control and synthesizing of these devices.

Md. Saiful Islam

Postgraduate (MSc. EEE), American International UniversityBangladesh (AIUB), Dhaka, Bangladesh.

E-mail: saifulislam007777@gmail.com

\section{Md. Rifat-Ul-Karim Shovon}

Graduate (BSc. EEE), American International UniversityBangladesh (AIUB), Dhaka, Bangladesh.

E-mail: rkshovon@hotmail.com

Dr. Mohammad Abdul Goffar Khan

Professor, Faculty of Engineering, Rajshahi University of Engineering \& Technology (RUET), Rajshahi, Bangladesh. E-mail: agmagk@gmail.com
Power conversion [16] from one form to another is required in case of the control of the electric power and the switching capability of the power devices permit these conversions. The most recent advancement in the power electronic circuits is the IGBT [17] due to its faster switching speed and lower switching and conduction losses having the three terminals: gate, collector and emitter. The most challenging task in a power conversion circuit is the development of control circuit [18]-[20]. Control circuit mainly depends on firing pulse. Firing pulse circuit can be two types, digital and analog. Analog circuit consist of electronic components which makes the circuit big in size and more complex. On the other hand, digitally controlled circuit such as microcontroller based firing pulse generation circuit become so much popular day by day because of its user friendly automatic controlling system and the circuit robustness.

It is observed that most of the researcher reported work on thyristor only. In the proposed work a microcontroller based firing circuit for single phase half-wave AC-DC converter will be implemented using both thyristor and IGBT in an integrated circuit and then performance will be evaluated with resistive load. In consequence the switching response will be fast and the switching loss would be minimized.

\section{CONTROLled ReCTIFIER}

\section{A. Silicon Controlled Rectifier (SCR or Thyristor)}

Controlled rectifiers are line commutated ac to dc power converters [21]-[22] which are used to convert a fixed voltage, fixed frequency ac power supply into variable DC output voltage.

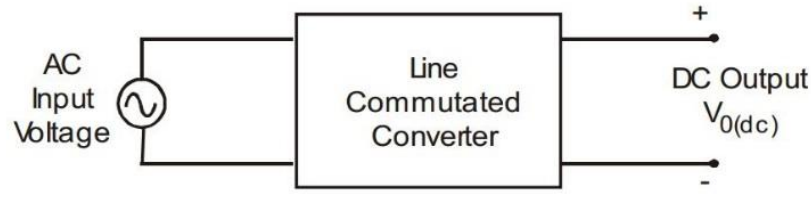

Fig. 1. Block diagram of AC-DC Converter

Fig. 1. shows the basic block diagram of ac-dc converter where the ac supply is fed to a controlled rectifier at a fixed rms voltage and at a fixed frequency. By employing phase controlled thyristor [23]-[25] in the controlled rectifier circuits variable dc output voltage and variable dc output current can be obtained by varying the firing angle (phase angle) [26]. The 
basic operation principle of single phase half wave ac-dc converter is shown in the Fig. 2. When the thyristor is fired at a firing angle of $\omega t=\alpha$, the thyristor conducts from $\omega t=\alpha$ to $\pi$ radians. For a purely resistive load, the load current $I o$ (output current) that flows when the thyristor is $\mathrm{ON}$, is given by the expression (1). The output load current waveform is in phase to the output load voltage waveform during the thyristor conduction time from $\alpha$ to $\pi$.

$$
i_{0}=\frac{v_{0}}{R_{L}}, \text { for } \alpha \leq \omega \mathrm{t} \leq \pi
$$

The firing angle $\alpha$ is measured from the beginning of each positive half cycle to the time instant when the gate firing pulse is applied. The input and output voltage wave shape of thyristor controlled ac-dc converter is shown in Fig. 3.

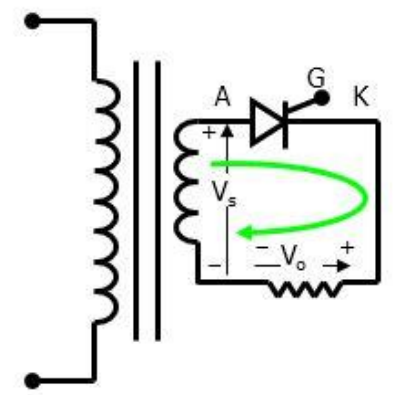

Fig. 2. Single phase half -wave thyristor controlled rectifier with resistive load

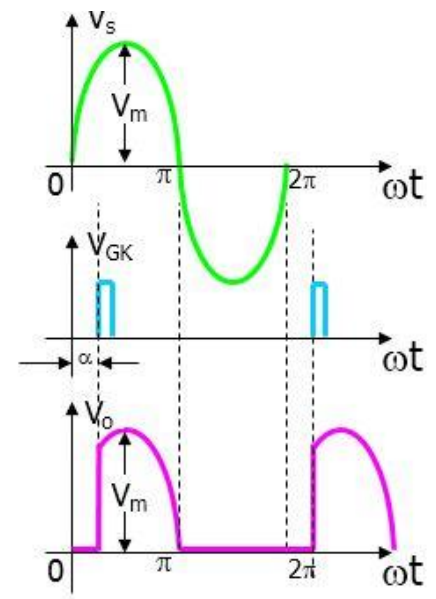

Fig. 3. Input and output voltage waveforms of single phase half-wave controlled rectifier with resistive load

The average dc output voltage is given by the expression (2) [27]

$$
V_{d c}=\frac{V_{m}}{2 \pi}[1+\cos \alpha]
$$

The relationship between average output voltage with firing angle is represented graphically in Fig. 4 where average output voltage maximum and minimum when the value of $\alpha$ is $0^{0}$ and $180^{\circ}$ respectively.

\section{B. Insulated Gate Bipolar Transistor (IGBT)}

Similarly, AC-DC power conversion can be obtained by considering Insulated Gate Bipolar Transistor (IGBT) [28]-[30] instead of thyristor. IGBT is a three terminal power device which was designed to turn on and turn off rapidly. An IGBT is turned on by just applying a positive gate voltage and is turned off by removing the gate voltage. The basic principle of operation for an IGBT is depicted in the Fig. 5 with resistive load and the respective input and output voltage with firing pulse is shown in Fig. 6.

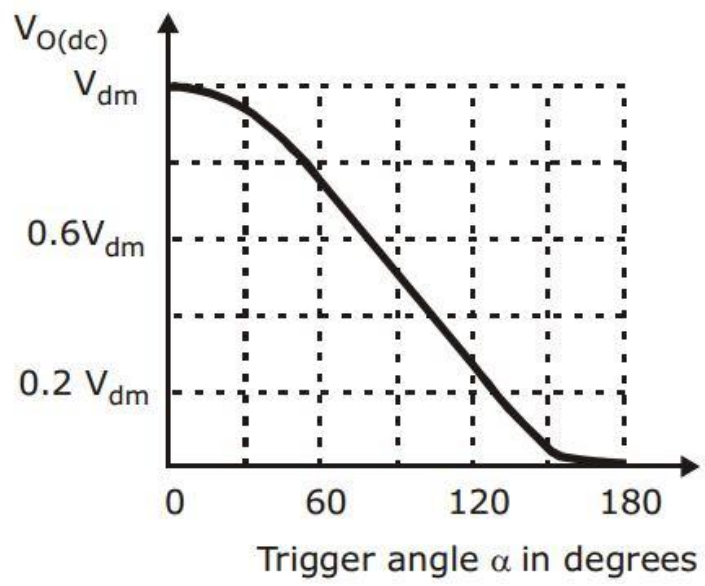

Fig. 4. Variation of output voltage with firing angle, $\alpha$

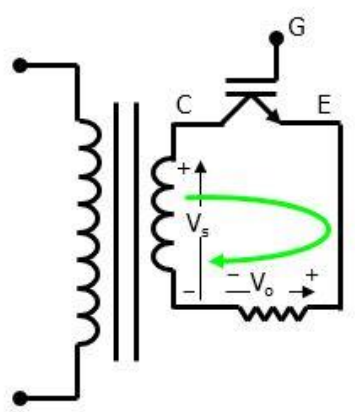

Fig. 5. Single phase half-wave AC-DC converter using IGBT with resistive load 


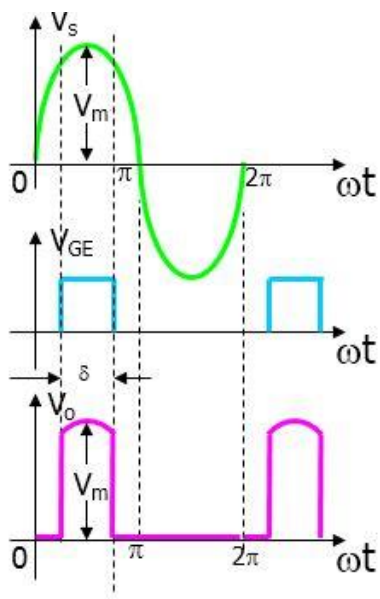

Fig. 6. Input and output voltage wave shape of IGBT based single phase half-wave controlled rectifier with resistive load

The average dc output voltage for this circuit is given by the expression (3),

$$
V_{d c}=\frac{V_{m}}{\pi} \sin \left(\frac{\delta}{2}\right)
$$

Here $\delta$ is the pulse width of the IGBT.

\section{Total Harmonic Distortion (THD)}

Harmonic factor or Total harmonic distortion is a measure of the distortion in the output waveform [31]. The distortion of the normal sine wave by non-linear loads is created by harmonics [32]. Harmonics are related to the fundamental frequency and are defined as whole number multiples of the fundamental frequency. THD of a signal is a measurement of the harmonic distortion present and is defined as the ratio of the sum of all harmonic components of the voltage or current waveform compared against the fundamental component of the voltage or current wave and the expression is (4) [4],

$$
T H D=\frac{\sqrt{I_{2}^{2}+I_{3}^{2}+\ldots \ldots \ldots \ldots+I_{N}^{2}}}{I_{1}}=\frac{\sqrt{\sum_{N=2}^{\infty} I_{N}^{2}}}{I_{1}}
$$

Where $\mathrm{I}_{\mathrm{N}}$ is the magnitude of the $\mathrm{N}_{\mathrm{th}}$ order harmonic component of the current.

\section{FIRING PULSE GENERATION}

To generate the firing pulse for Thyristor and IGBT an isolated firing pulse circuit developed using multi-winding transformer [33]. The block diagram and flowchart diagram shown in Fig. 7 \& Fig. 8 gives an overall idea about the sequence of the firing pulse generation circuit. The proposed firing pulse circuit consist of zero crossing detector circuit, opto-coupler, microcontroller unit, variable potentiometer to control analog voltage for different firing angle generation.

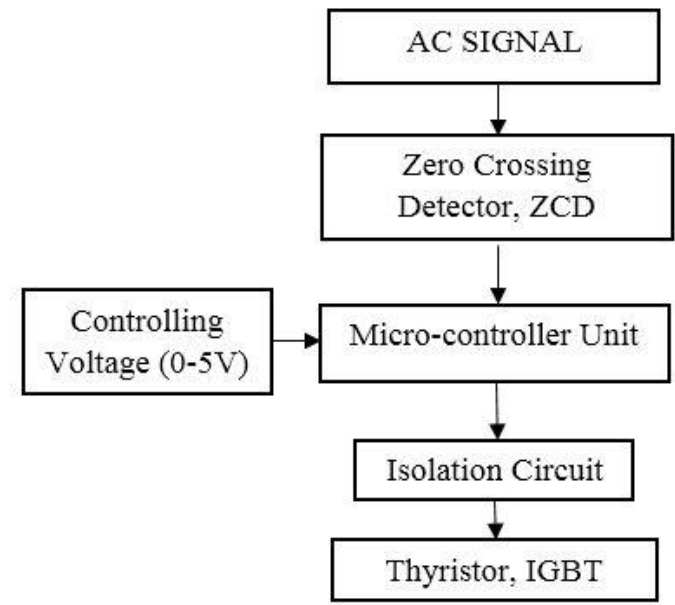

Fig. 7. Block diagram of the firing pulse generation circuit

Integration of all these blocks achieves full controlled converter with advanced performance over other regular techniques. Zero Crossing Detector (ZCD) [34]-[35] module detects the start of positive half cycles or negative half cycles for synchronization of the firing pulses to power supply mains. A potentiometer arrangement is used for varying the control voltage corresponding to different firing angle. The analog voltage received by the microcontroller is converted to digital counts $(0-1023)$ and fed to the inbuilt ADC port within the microcontroller.

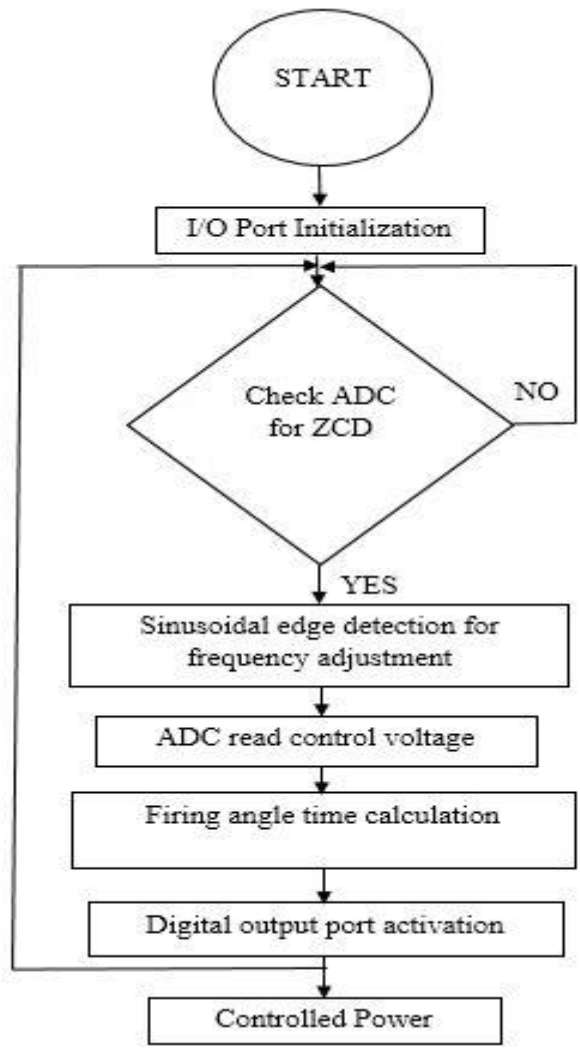

Fig. 8. Flow chart of the firing pulse generation circuit 


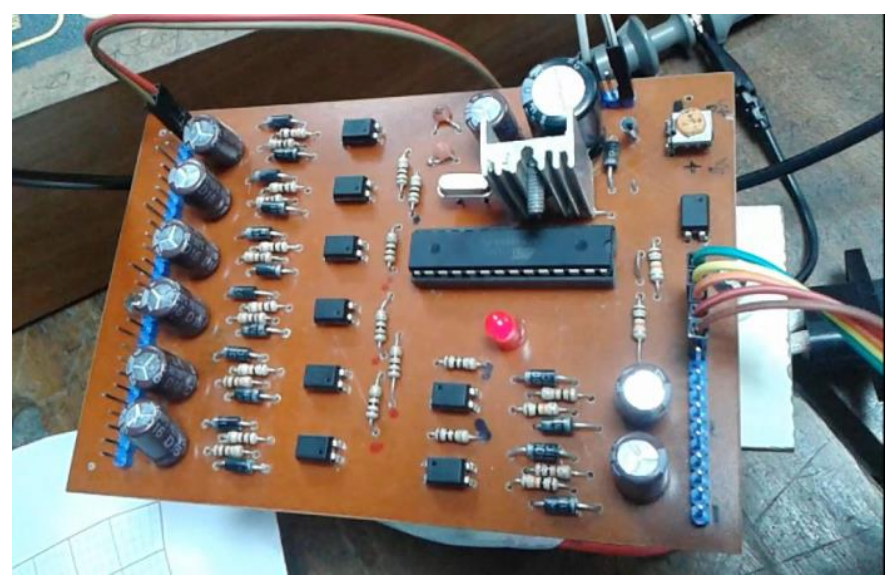

Fig. 9. Photograph of the fabricated circuit

The change in the input analog voltage shall be proportionately converted to the change in digital count. Micro-controller unit accepts analog voltage for the ADC port through the customized potentiometer. At any time when zero crossing (falling edge of square wave) is detected on the AC mains, microcontroller is interrupted and the latest values of ADC is used to determine firing angle with proper mathematical calculations. To control firing pulses from $0^{0}-180^{\circ} \mathrm{ADC}$ output ranges between $0-1023$ counts. The firing pulse generation circuit is fabricated and tested in the lab successfully. A photograph of the firing pulse generation circuit is shown in Fig. 9.

\section{MATLAB Simulations}

\section{A. Thyristor Controlled AC-DC Converter}

MATLAB/SIMULINK software is used to model a thyristor and IGBT based AC-DC converter circuit with resistive load. The average output voltage $\left(\mathrm{V}_{\mathrm{dc}}\right)$ and Total Harmonic Distortion (THD) is obtained by controlling the firing angle of the thyristor. The circuit is simulated for both thyristor and IGBT, under the same output voltage condition. Fig. 10 shows the thyristor based AC-DC converter circuit with resistive load.

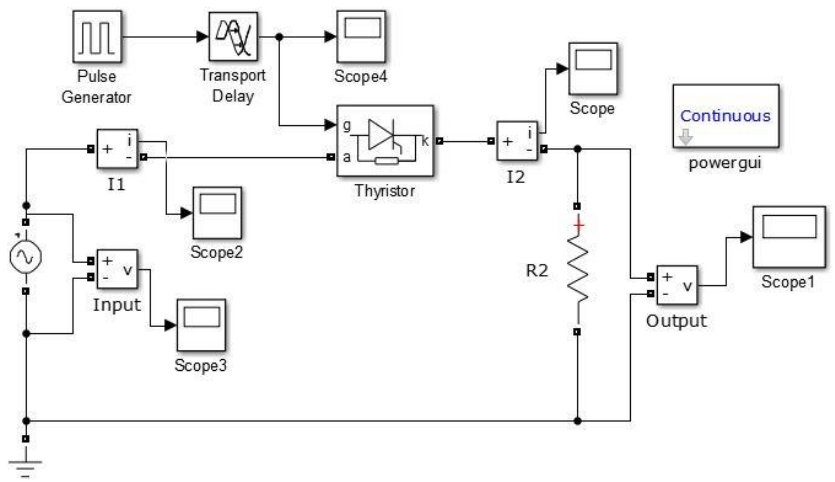

Fig. 10. AC-DC converter circuit using thyristor in MATLAB/SIMULINK
The circuit is tested by considering the following parameters shown in Table I and the firing angle is measured in terms of control voltage $(0-5 \mathrm{~V})$ and is represented in the following Table II with equivalent time period in milliseconds.

Table I: Parameters used for simulation

\begin{tabular}{|c|c|c|c|}
\hline $\begin{array}{c}\text { Voltage, } \\
\text { Vrms }\end{array}$ & $\begin{array}{c}\text { Frequency, } \\
\mathrm{Hz}\end{array}$ & $\begin{array}{c}\text { Peak Voltage, } \\
\text { Vm }\end{array}$ & $\begin{array}{c}\text { Load } \\
\text { Resistance, } \mathrm{R}\end{array}$ \\
\hline $220 \mathrm{~V}$ & $50 \mathrm{~Hz}$ & $311 \mathrm{~V}$ & $10 \mathrm{ohm}$ \\
\hline
\end{tabular}

Table II: Firing angle relationship with corresponding time

\begin{tabular}{|c|c|c|c|c|c|}
\hline $\begin{array}{c}\text { Firing } \\
\text { angle, } \alpha \text { in } \\
\text { degree }\end{array}$ & $30^{0}$ & $60^{\circ}$ & $90^{0}$ & $120^{0}$ & $150^{\circ}$ \\
\hline $\begin{array}{c}\text { Control } \\
\text { voltage }(0- \\
5 \mathrm{~V})\end{array}$ & 0.833 & 1.67 & 2.50 & 3.33 & 4.17 \\
\hline $\begin{array}{c}\text { Time } \\
\text { period }(\mathrm{T}) \\
\text { in } \\
\text { millisecond }\end{array}$ & 1.6667 & 3.3333 & 5 & 6.6667 & 8.333 \\
\hline
\end{tabular}

At first thyristor is fired at $\alpha=30^{\circ}$, the corresponding output voltage $\left(\mathrm{V}_{\mathrm{dc}}\right)$ and Total Harmonic Distortion (THD) is obtained $98 \mathrm{~V}$ and $55.01 \%$ respectively. Thyristor output voltage wave shape and THD is shown in Fig. 11 \& Fig. 12 respectively.

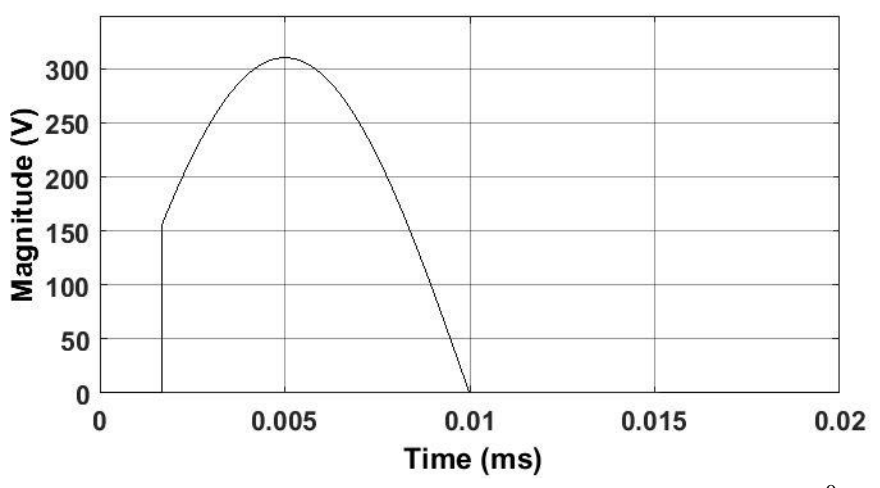

Fig. 11. Simulated Output voltage of thyristor fired at $30^{0}$
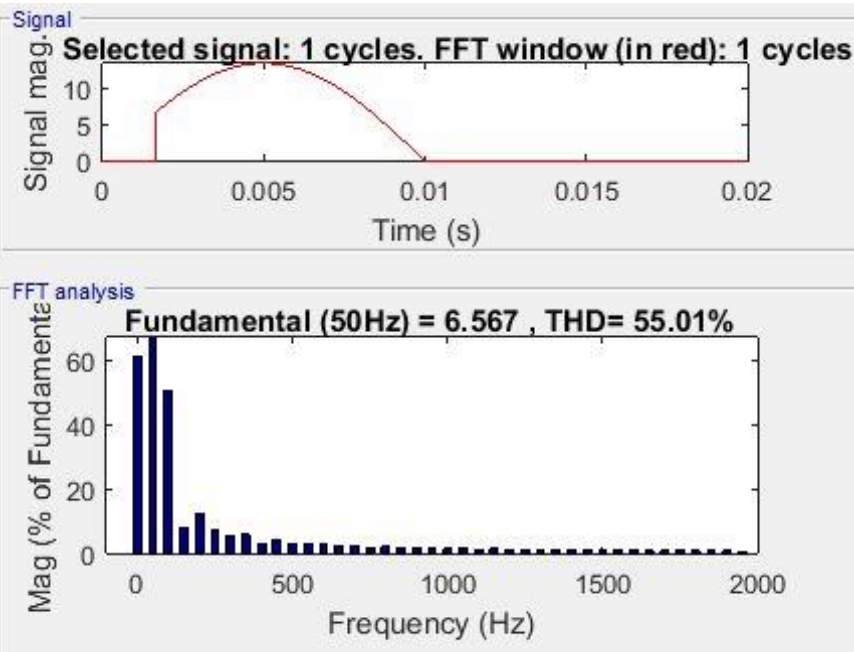
Fig. 12. Simulated THD of thyristor fired at $30^{\circ}$

Next thyristor is fired at $\alpha=60^{\circ}$, the corresponding output voltage $\left(\mathrm{V}_{\mathrm{dc}}\right)$ and Total Harmonic Distortion (THD) is obtained $78.78 \mathrm{~V}$ and $80.02 \%$ respectively. Thyristor output voltage wave shape and THD is shown in Fig. 13 \& Fig. 14 respectively.

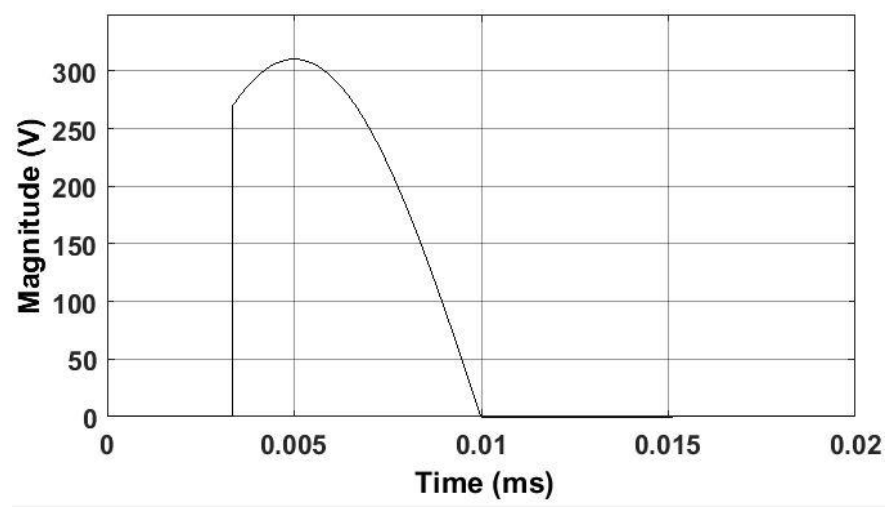

Fig. 13. Output voltage of thyristor fired at $60^{\circ}$

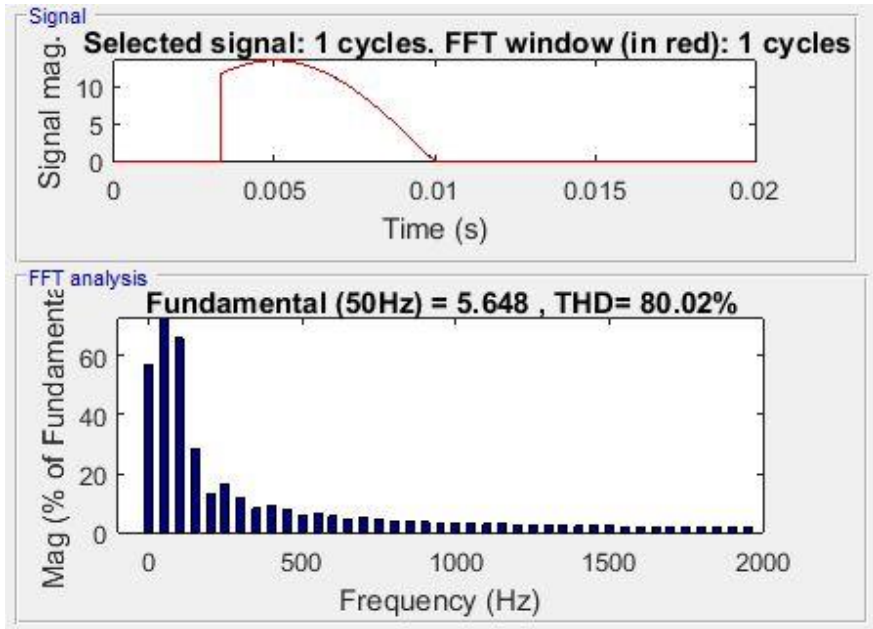

Fig. 14. THD of thyristor fired at $60^{\circ}$

Similarly thyristor is fired at $\alpha=90^{\circ}$, the corresponding output voltage $\left(\mathrm{V}_{\mathrm{dc}}\right)$ and Total Harmonic Distortion (THD) is obtained $52.52 \mathrm{~V}$ and $113.31 \%$ respectively. Thyristor output voltage wave shape and THD is shown in Fig. 15 \& Fig. 16 respectively.

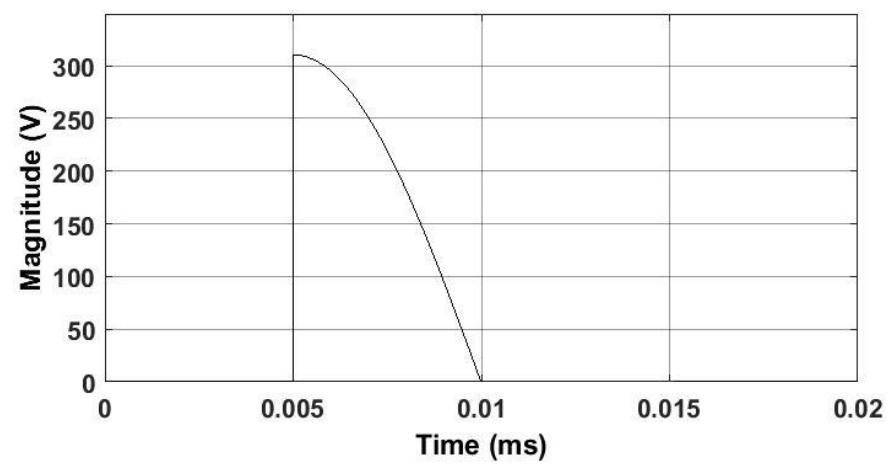

Fig. 15. Output voltage of thyristor fired at $90^{\circ}$

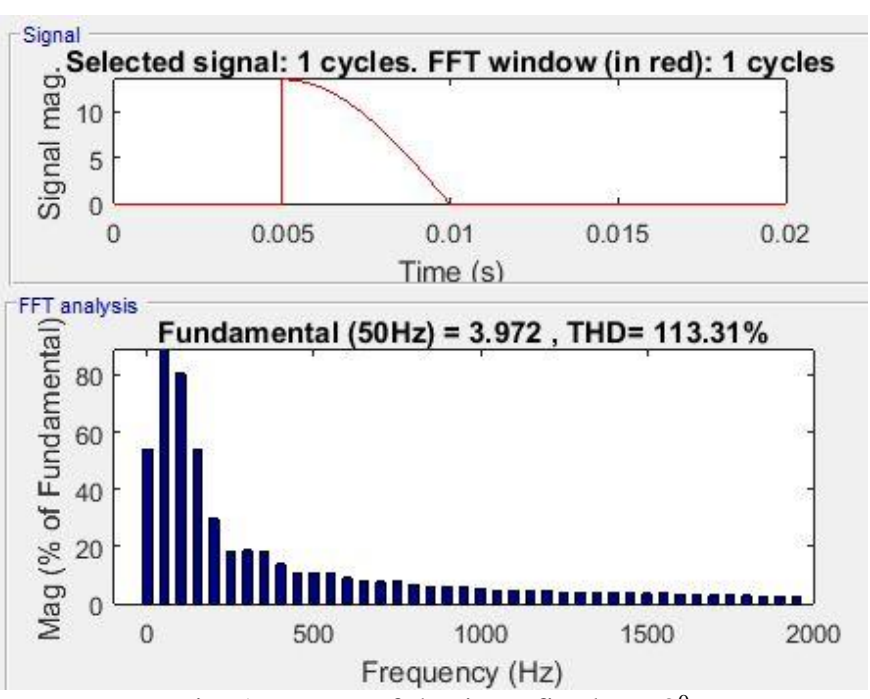

Fig. 16. THD of thyristor fired at $90^{\circ}$

Again thyristor is fired at $\alpha=120^{\circ}$, the corresponding output voltage $\left(\mathrm{V}_{\mathrm{dc}}\right)$ and Total Harmonic Distortion (THD) is obtained $26.26 \mathrm{~V}$ and $162.21 \%$ respectively. Thyristor output voltage wave shape and THD is shown in Fig. 17 \& Fig. 18 respectively.

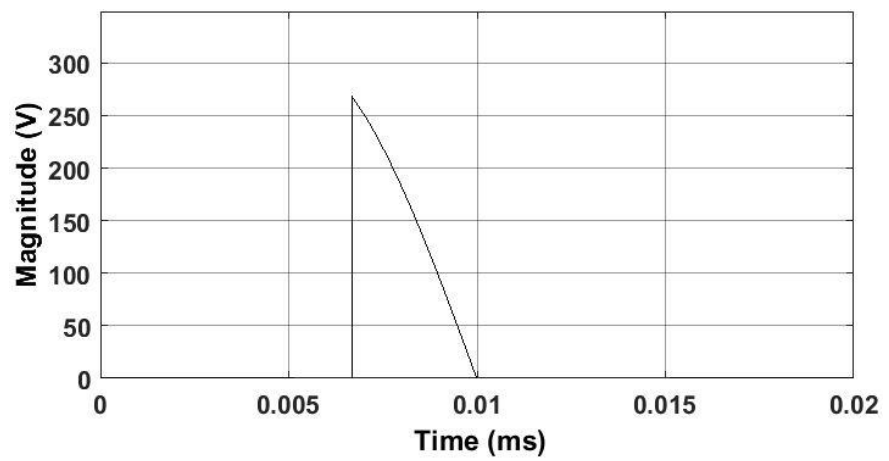

Fig. 17. Output voltage of thyristor fired at $120^{\circ}$

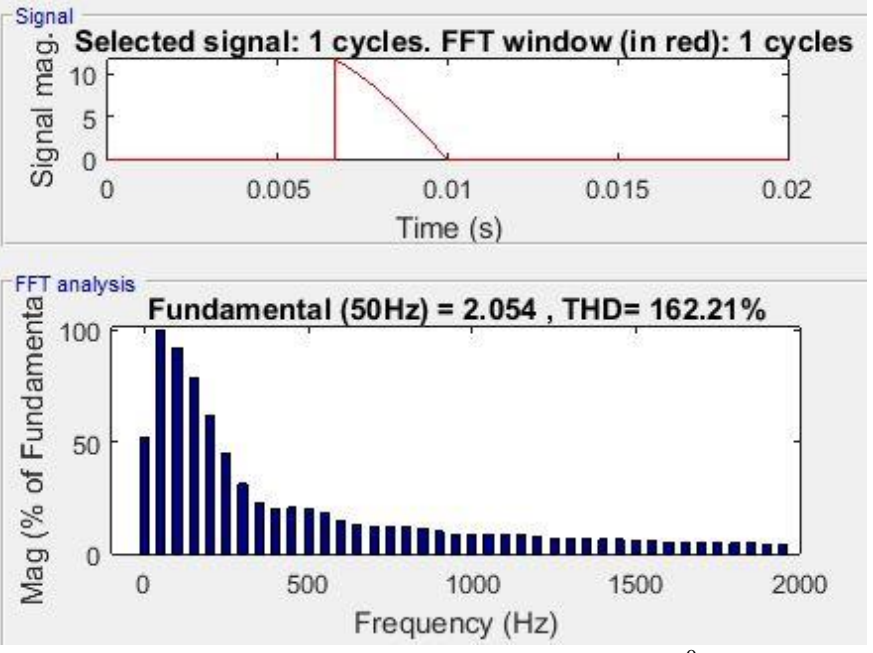

Fig. 18. THD of thyristor fired at $120^{\circ}$ 
At last thyristor is fired at $\alpha=150^{\circ}$, the corresponding output voltage (Vdc) and Total Harmonic Distortion (THD) is obtained $7.04 \mathrm{~V}$ and $266.79 \%$ respectively. Thyristor output voltage wave shape and THD is shown in Fig. 19 \& Fig. 20 respectively.

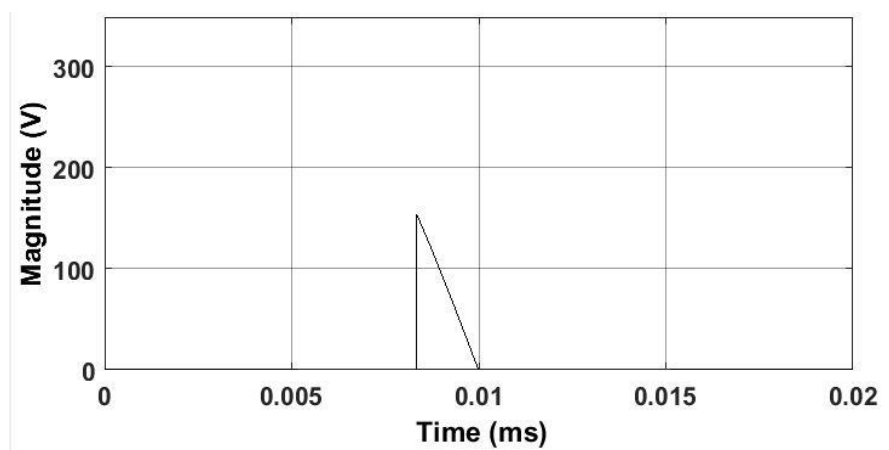

Fig. 19. Output voltage of thyristor fired at $150^{\circ}$
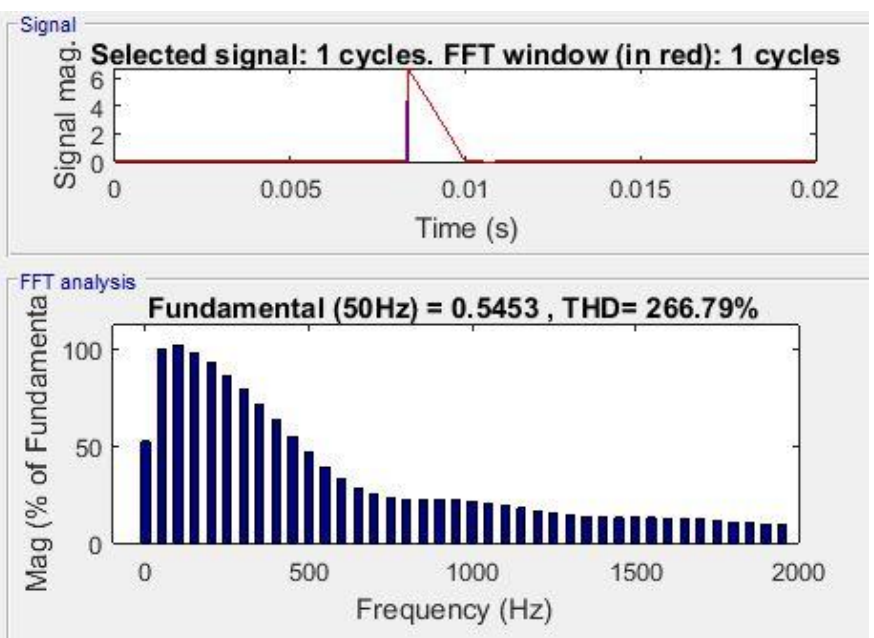

Fig. 20. THD of thyristor fired at $150^{\circ}$

\section{B. IGBT Controlled AC-DC Converter}

An IGBT based AC-DC converter also simulated as well as in MATLAB/SIMULINK for resistive load only, as shown in Fig. 21 . The parameters are taken as same as in thyristor in Table I.

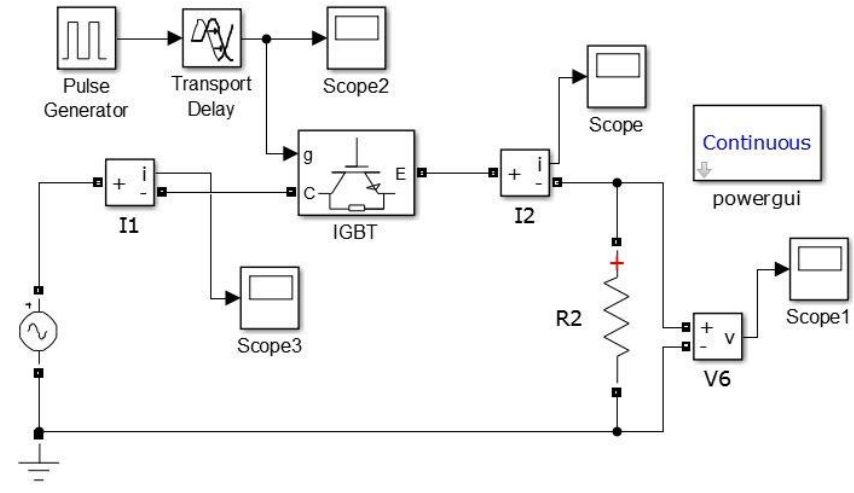

Fig. 21. AC-DC converter circuit using IGBT in MATLAB/SIMULINK

The following Table III represents the firing angle of thyristor with corresponding output voltage and pulse width of IGBT for various condition. For the initial simulation pulse width of IGBT is considered $\delta=137.82^{0}$ which corresponds to the firing angle of thyristor, $\alpha=30^{\circ}$ for the same output voltage, $\mathrm{Vdc}=$ 98V. For this pulse width Total Harmonic Distortion (THD) obtained from simulation is $55.38 \%$. The output voltage wave shape and THD is shown in Fig. 22 \& Fig. 23 respectively.

Table III: IGBT pulse width and output voltage with corresponding thyristor firing angle

\begin{tabular}{|c|c|c|}
\hline $\begin{array}{c}\text { Thyristor firing } \\
\text { angle, } \alpha \text { in } \\
\text { degree }\end{array}$ & $\begin{array}{c}\text { Average output } \\
\text { voltage, } \mathrm{V}_{\mathrm{dc}} \text { in } \\
\text { volt }\end{array}$ & $\begin{array}{c}\text { IGBT pulse width, } \\
\delta \text { in degree }\end{array}$ \\
\hline $30^{0}$ & 98.00 & $137.82^{0}$ \\
\hline $60^{0}$ & 78.78 & $97.18^{0}$ \\
\hline $90^{0}$ & 52.52 & $59.99^{0}$ \\
\hline $120^{0}$ & 26.26 & $28.96^{0}$ \\
\hline $150^{0}$ & 7.03 & $7.68^{0}$ \\
\hline
\end{tabular}

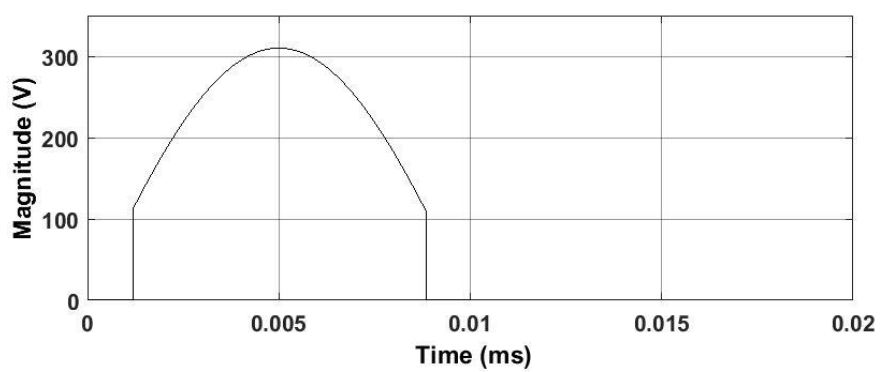

Fig. 22. Output voltage wave shape of IGBT for pulse width $\delta=137.82^{0}$

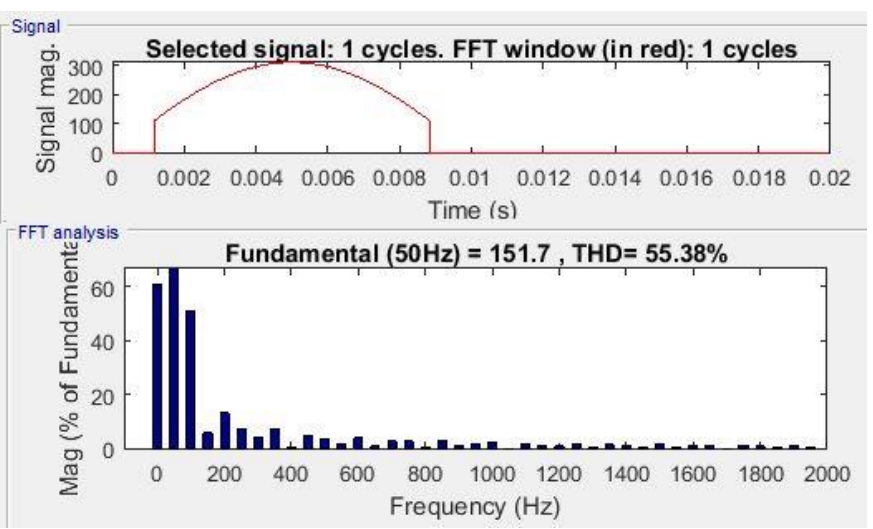

Fig. 23. THD for pulse width $\delta=137.82^{0}$

For the next simulation pulse width of IGBT is considered $\delta=$ $97.18^{0}$ which corresponds to the firing angle of thyristor, $\alpha=60^{\circ}$ for the same output voltage, $\mathrm{Vdc}=78.78 \mathrm{~V}$. For this pulse width Total Harmonic Distortion (THD) obtained from simulation is $84.59 \%$. The output voltage wave shape and THD is shown in Fig. 24 \& Fig. 25 respectively. 


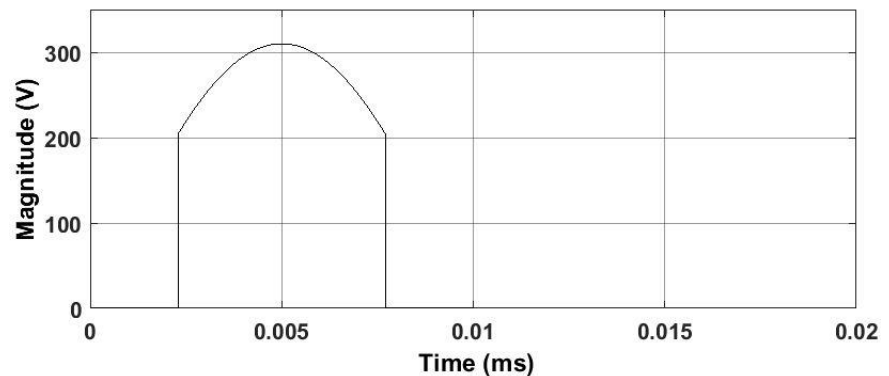

Fig. 24. Output voltage wave shape of IGBT for Pulse width $\delta=97.18^{0}$

Again for the simulation pulse width of IGBT is considered $\delta=$ $59.99^{\circ}$ which corresponds to the firing angle of thyristor, $\alpha=90^{\circ}$ for the same output voltage, $\mathrm{V}_{\mathrm{dc}}=52.52 \mathrm{~V}$. For this pulse width Total Harmonic Distortion (THD) obtained from simulation is $131.41 \%$. The output voltage wave shape and THD is shown in Fig. 26 \& Fig. 27 respectively.

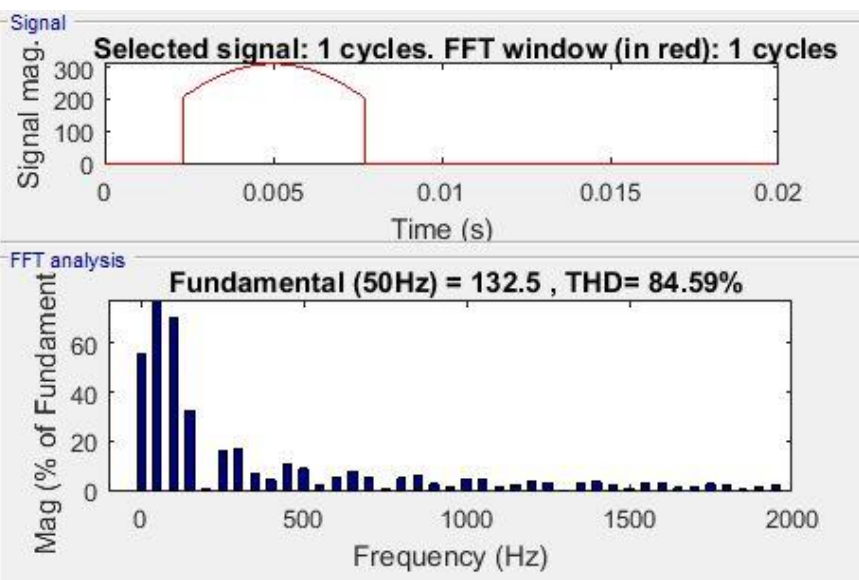

Fig. 25. THD for pulse width $\delta=97.18^{\circ}$

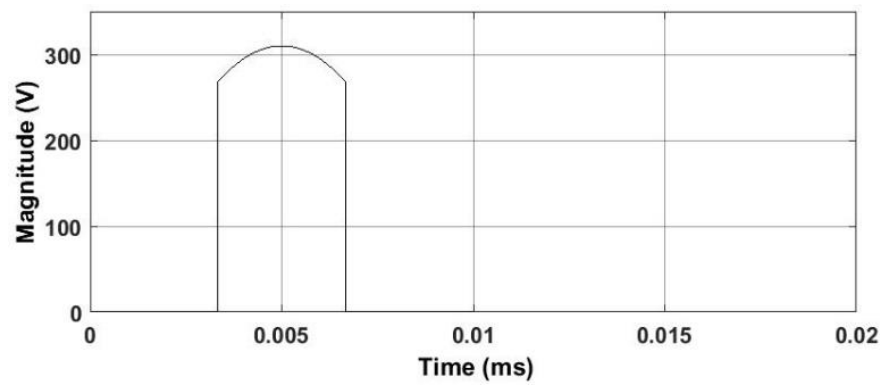

Fig. 26. Output voltage wave shape of IGBT for Pulse width $\delta=59.99^{\circ}$
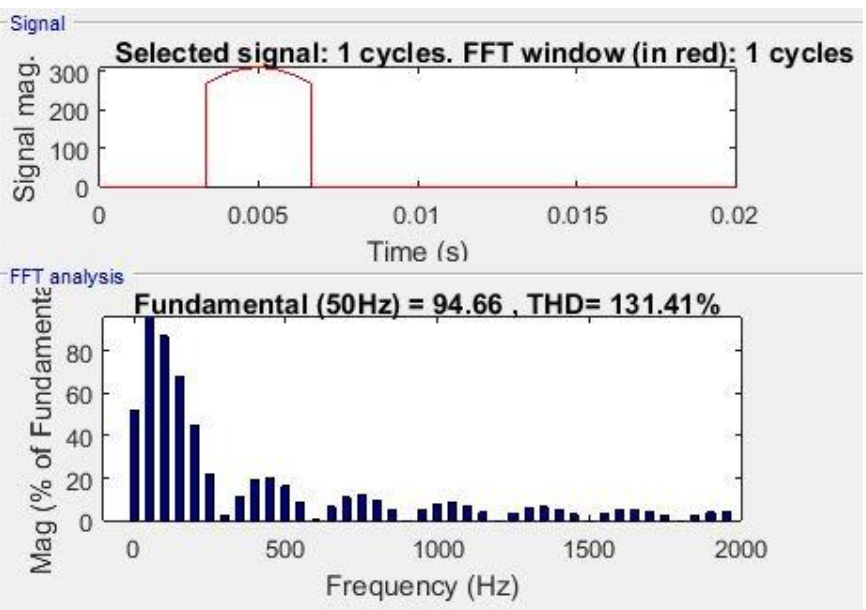

Fig. 27. THD for pulse width $\delta=59.99^{0}$

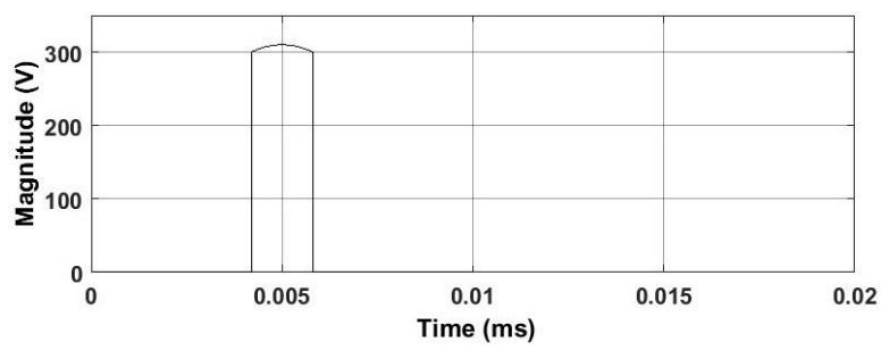

Fig. 28. Output voltage wave shape of IGBT for Pulse width $\delta=28.96^{0}$

Similarly for the simulation pulse width of IGBT is considered $\delta=28.96^{\circ}$ which corresponds to the firing angle of thyristor, $\alpha=120^{\circ}$ for the same output voltage, $\mathrm{V}_{\mathrm{dc}}=26.26 \mathrm{~V}$. For this pulse width Total Harmonic Distortion (THD) obtained from simulation is $219.31 \%$. The output voltage wave shape and THD is shown in Fig. 28 \& Fig. 29 respectively.

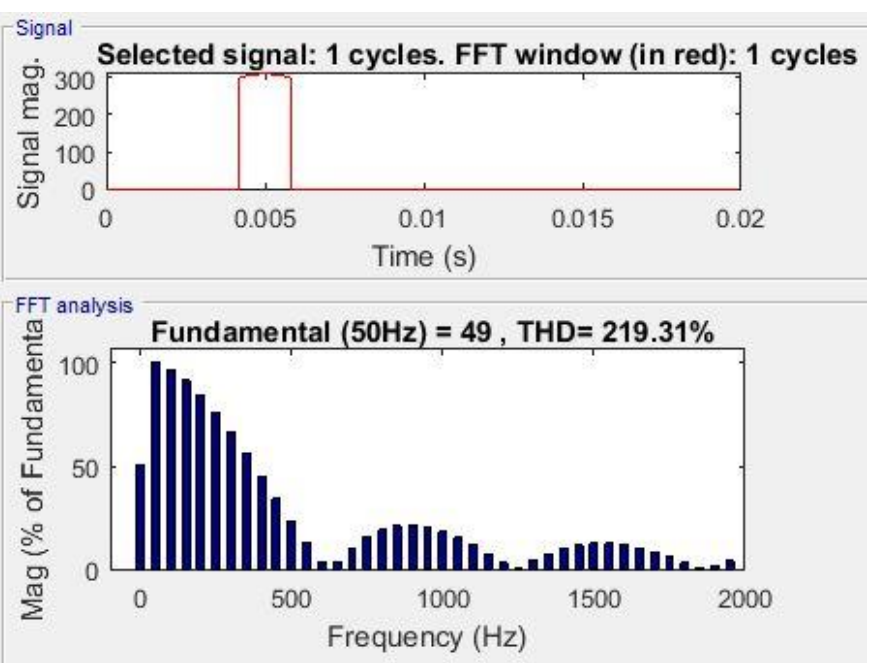

Fig. 29. THD for pulse width $\delta=28.96^{0}$

Lastly for the simulation pulse width of IGBT is considered $\delta=$ $7.68^{0}$ which corresponds to the firing angle of thyristor, $\alpha=150^{\circ}$ for the same output voltage, $\mathrm{V}_{\mathrm{dc}}=7.03 \mathrm{~V}$. For this pulse width Total Harmonic Distortion (THD) obtained from simulation is 
465.41\%. The output voltage wave shape and THD is shown in Fig. 30 \& Fig. 31 respectively.

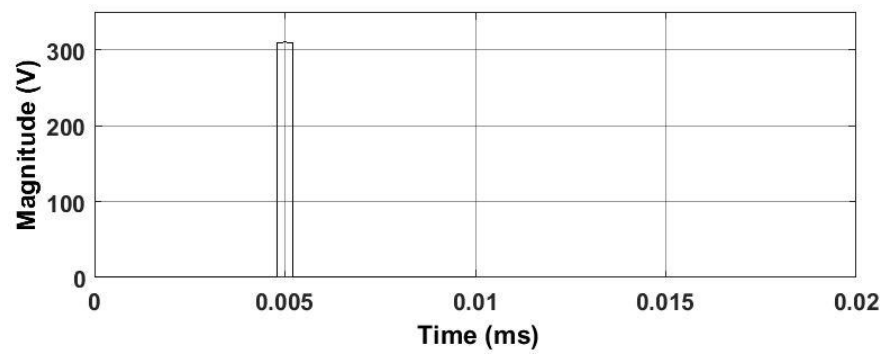

Fig. 30. Output voltage wave shape of IGBT for Pulse width $\delta=7.68^{0}$

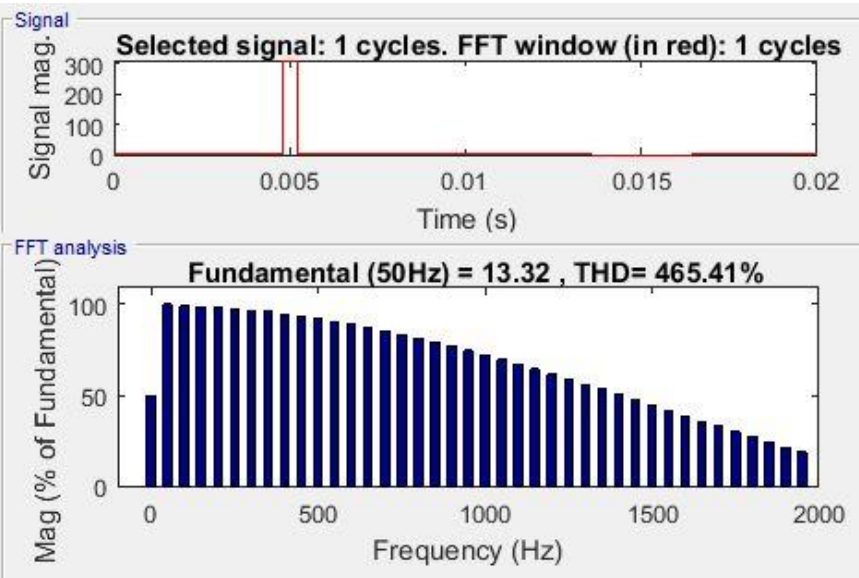

Fig. 31. THD for pulse width $\delta=7.68^{0}$

It is observed that percentage of THD increased along with the increase of firing angle of thyristor as well as IGBT. A summary of the results of THD for thyristor and IGBT is represented in Table IV.

Table IV: Summary of THD for Thyristor and IGBT

\begin{tabular}{|c|c|c|c|c|}
\hline \multicolumn{3}{|c|}{ Thyristor } & \multicolumn{2}{|c|}{ IGBT } \\
\hline $\begin{array}{c}\text { Firing } \\
\text { in degree } \alpha\end{array}$ & $\begin{array}{c}\text { Average } \\
\text { output } \\
\text { voltage } \\
\left(\mathrm{V}_{\mathrm{dc}}\right) \text { in Volt }\end{array}$ & $\begin{array}{c}\text { THD } \\
(\%)\end{array}$ & $\begin{array}{c}\text { Pulse } \\
\text { width, } \delta \\
\text { in degree }\end{array}$ & $\begin{array}{c}\text { THD } \\
(\%)\end{array}$ \\
\hline $30^{0}$ & 98.00 & 55.00 & $137.82^{0}$ & 55.38 \\
\hline $60^{0}$ & 78.78 & 79.35 & $97.18^{0}$ & 84.59 \\
\hline $90^{0}$ & 52.52 & 111.63 & $59.99^{0}$ & 131.41 \\
\hline $120^{0}$ & 26.26 & 158.79 & $28.96^{0}$ & 219.31 \\
\hline $150^{0}$ & 7.04 & 252.97 & $7.68^{0}$ & 465.41 \\
\hline
\end{tabular}

\section{EXPERIMENTAL RESULTS}

\section{A. Silicon Controlled AC-DC Converter (SCR or Rectifier)}

The firing pulse circuit is developed in the laboratory to verify the simulation results with experimental observation. A $12 \mathrm{~V}$ prototype circuit is implemented and tested with a $25 \mathrm{~W}$ incandescent lamp as a load in the laboratory. Parameters used in the test are given in Table V.

\section{B. Digital Oscilloscope Rigol DS1000Z Series}

To analyze the Total Harmonic Distortion (THD) and output voltage wave shape a special type of 4 channel digital oscilloscope is shown in Fig. 32 took in consideration in this research. The main features of DS1054Z is presented in Table VI.

Table V: Parameters used for laboratory experiment

\begin{tabular}{|c|c|c|c|c|}
\hline $\begin{array}{c}\text { Voltage, } \\
\text { Vrms }\end{array}$ & $\begin{array}{c}\text { Frequency, } \\
\mathrm{Hz}\end{array}$ & $\begin{array}{c}\text { Peak } \\
\text { Voltage, } \\
\text { Vm }\end{array}$ & $\begin{array}{c}\text { Load } \\
\text { Resistor, } \\
\mathrm{R}\end{array}$ & $\begin{array}{c}\text { Load } \\
\text { Power, } \\
\mathrm{P}\end{array}$ \\
\hline $12 \mathrm{~V}$ & $50 \mathrm{~Hz}$ & $16.6 \mathrm{~V}$ & $23 \mathrm{ohm}$ & $25 \mathrm{~W}$ \\
\hline
\end{tabular}

Table VI: DS1054Z function parameters

\begin{tabular}{|c|c|}
\hline Waveform Operation & $\mathrm{A}+\mathrm{B}, \mathrm{A}-\mathrm{B}, \mathrm{A} \times \mathrm{B}, \mathrm{A} / \mathrm{B}, \mathrm{FFT}$ \\
\hline FFT Window Function & $\begin{array}{c}\text { Rectangle, Hanning, } \\
\text { Triangle, Blackman, Flat } \\
\text { top }\end{array}$ \\
\hline FFT Mode & Trace, Memory \\
\hline FFT Display & Half, Full \\
\hline FFT Vertical Scale & dB/dBm, Vrms \\
\hline Standard Ports & USB Host, USB Device, \\
& LAN \\
\hline Sample Rate & $200 \mathrm{MSa} / \mathrm{s}$ \\
\hline Max. Frequency & $25 \mathrm{MHz}$ \\
\hline Number of channel & $4 \mathrm{nos}$ \\
\hline
\end{tabular}

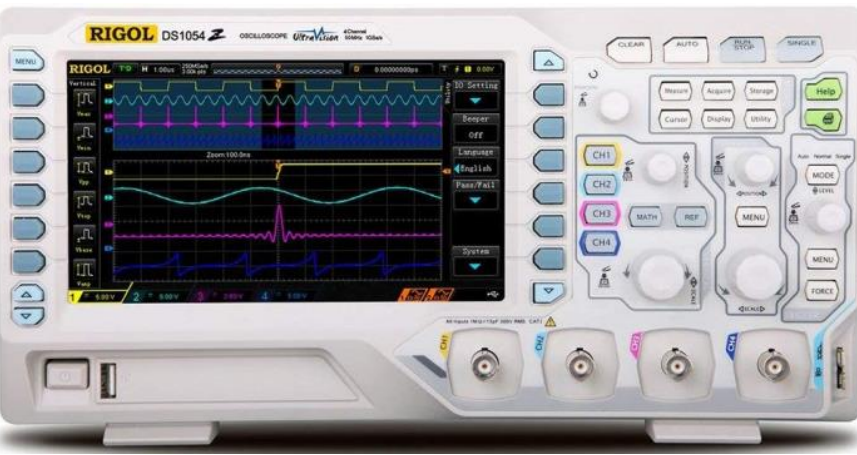

Fig. 32. Front view of DS1054Z oscilloscope

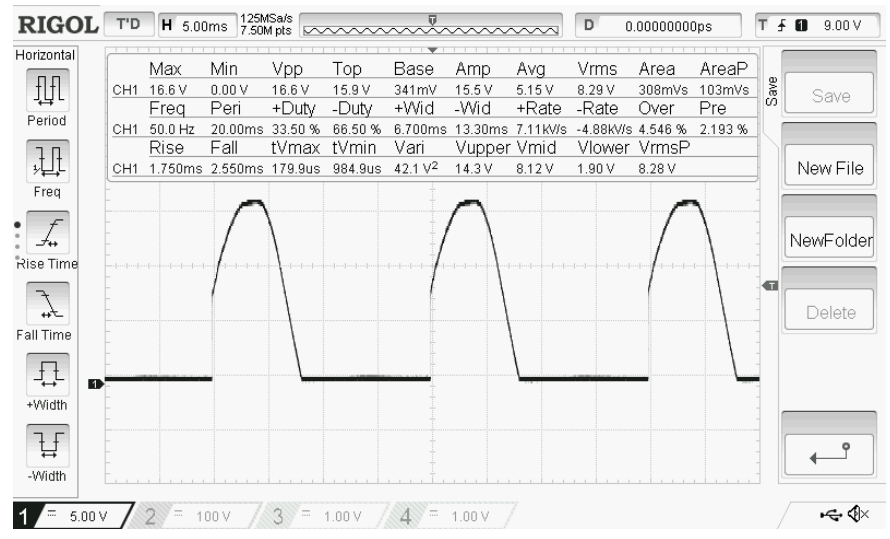


Fig. 33. Output voltage wave shape of thyristor fired at $30^{\circ}$ captured by oscilloscope

At first the thyristor firing pulse considered as $\alpha=30^{\circ}$. For this firing pulse observed data found in oscilloscope is $\mathrm{Vdc}=5.17 \mathrm{~V}$, $\mathrm{V}_{\mathrm{rms}}=8.28 \mathrm{~V}$ and $\mathrm{V}_{\mathrm{m}}=16.6 \mathrm{~V}$. The output voltage wave shape and THD is shown in Fig. 33 and Fig. 34.

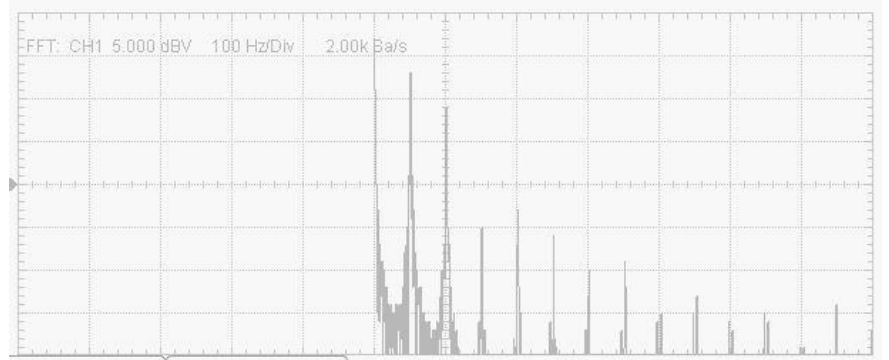

Fig. 34. THD of thyristor fired at $30^{\circ}$ captured by oscilloscope

Next the thyristor firing pulse considered as $\alpha=60^{\circ}$. For this firing pulse observed data found in oscilloscope is $\mathrm{Vdc}=4.50 \mathrm{~V}$, $\mathrm{V}_{\mathrm{rms}}=7.87 \mathrm{~V}$ and $\mathrm{V}_{\mathrm{m}}=16.6 \mathrm{~V}$. The output voltage wave shape and THD is shown in Fig. 35 and Fig. 36.

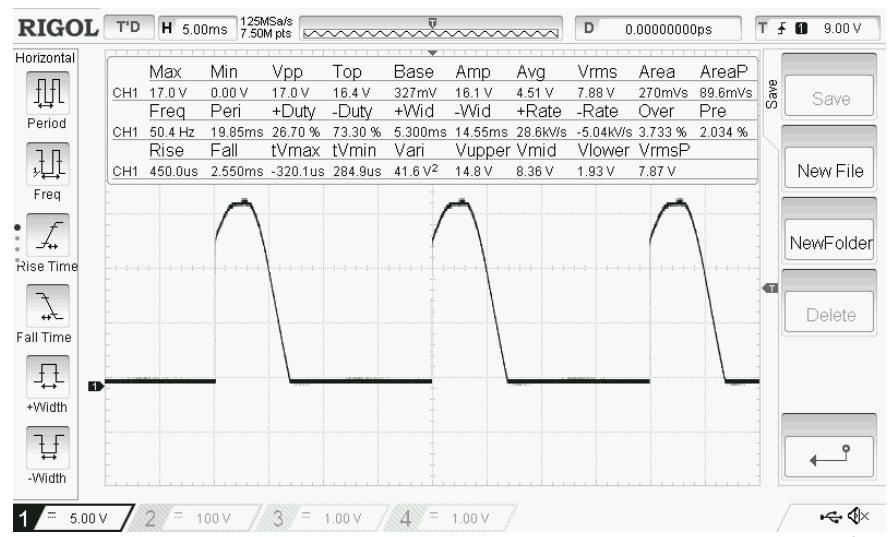

Fig. 35. Output voltage wave shape of thyristor fired at $60^{\circ}$ captured by oscilloscope

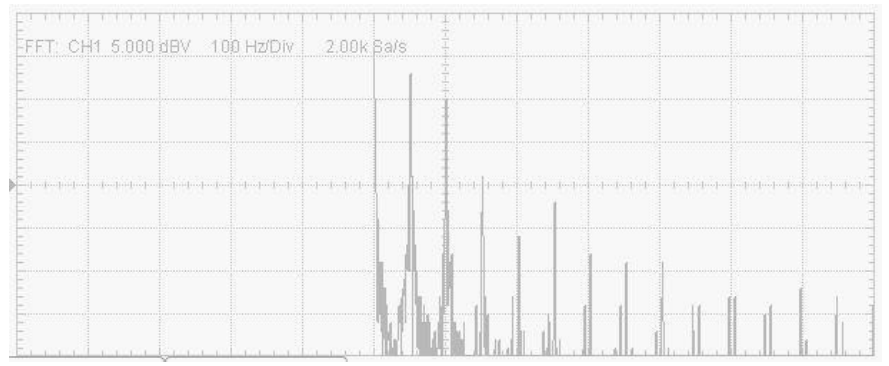

Fig. 36. THD of thyristor fired at $60^{\circ}$ captured by oscilloscope

Again the thyristor firing pulse considered as $\alpha=90^{\circ}$. For this firing pulse observed data found in oscilloscope is $\mathrm{Vdc}=3.62 \mathrm{~V}$, $\mathrm{V}_{\mathrm{rms}}=6.94 \mathrm{~V}$ and $\mathrm{V}_{\mathrm{m}}=16.6 \mathrm{~V}$. The output voltage wave shape and THD is shown in Fig. 37 and Fig. 38.

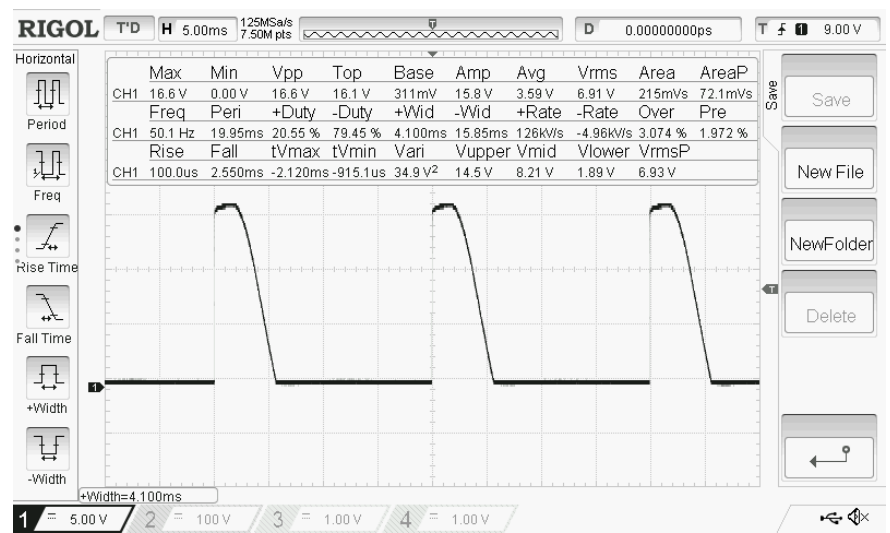

Fig. 37. Output voltage wave shape of thyristor fired at $90^{0}$ captured by oscilloscope

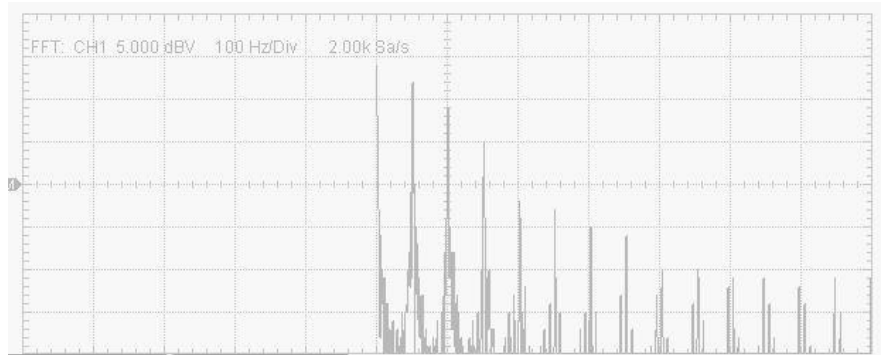

Fig. 38. THD of thyristor fired at $90^{\circ}$ captured by oscilloscope Similarly the thyristor firing pulse considered as $\alpha=120^{\circ}$. For this firing pulse observed data found in oscilloscope is $\mathrm{Vdc}$ $=3.09 \mathrm{~V}, \mathrm{~V}_{\mathrm{rms}}=6.24 \mathrm{~V}$ and $\mathrm{V}_{\mathrm{m}}=16.6 \mathrm{~V}$. The output voltage wave shape and THD is shown in Fig. 39 and Fig. 40.

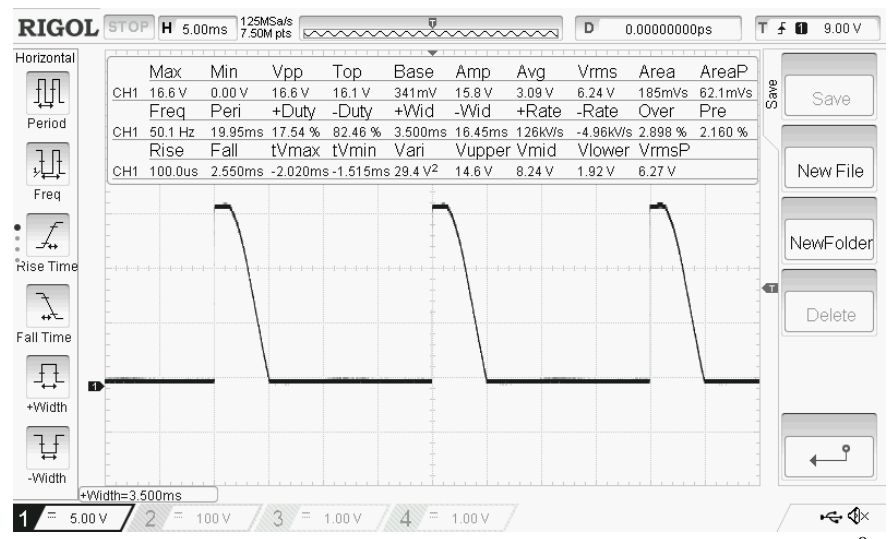

Fig. 39. Output voltage wave shape of thyristor fired at $120^{\circ}$ captured by oscilloscope

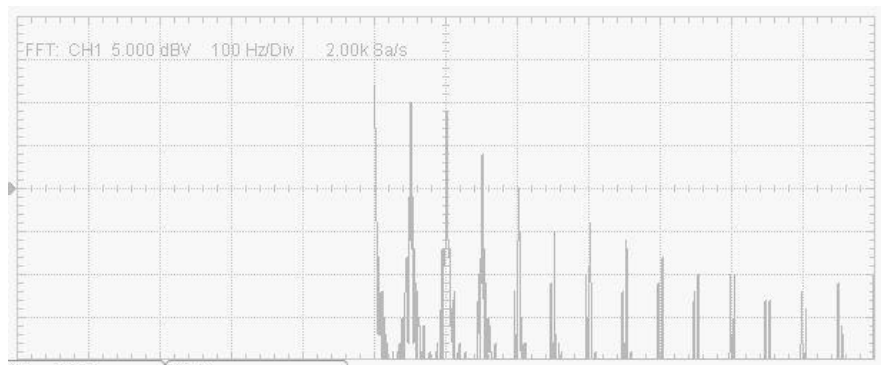

Fig. 40. THD of thyristor fired at $120^{\circ}$ captured by oscilloscope 
Finally the thyristor firing pulse considered as $\alpha=150^{\circ}$. For this firing pulse observed data found in oscilloscope is $\mathrm{Vdc}=1.51 \mathrm{~V}$, $\mathrm{V}_{\mathrm{rms}}=3.57 \mathrm{~V}$ and $\mathrm{V}_{\mathrm{m}}=16.6 \mathrm{~V}$. The output voltage wave shape and THD is shown in Fig. 41 and Fig. 42.

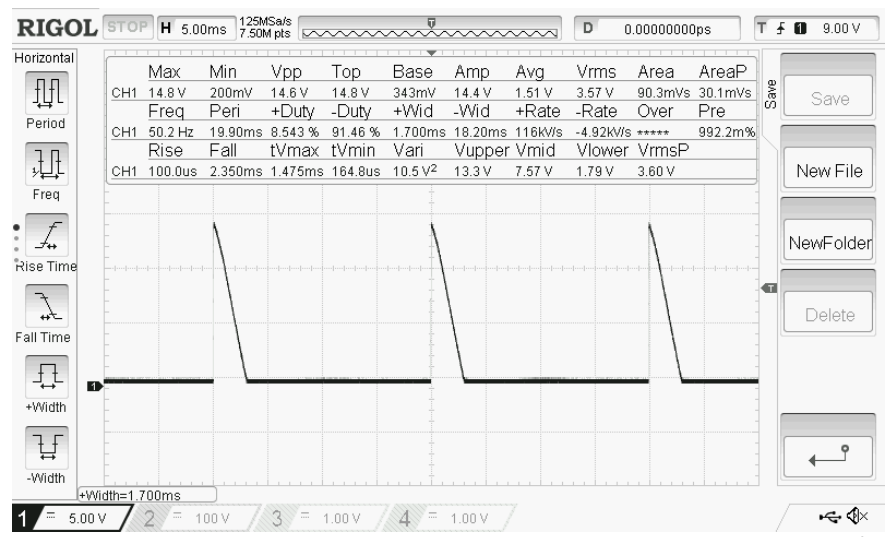

Fig. 41. Output voltage wave shape of thyristor fired at $150^{\circ}$ captured by oscilloscope

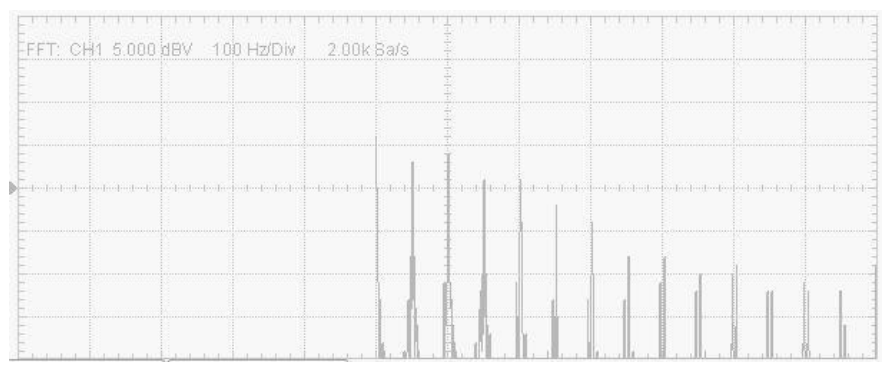

Fig. 42. THD of thyristor fired at $150^{\circ}$ captured by oscilloscope

\section{B. IGBT Controlled AC-DC Converter}

Similarly for IGBT experimental work done by taking all the parameters are equal as in thyristor. Pulse width of IGBT found in oscilloscope converted from millisecond to degree. THD calculation using the oscilloscope DS1054Z is not possible.

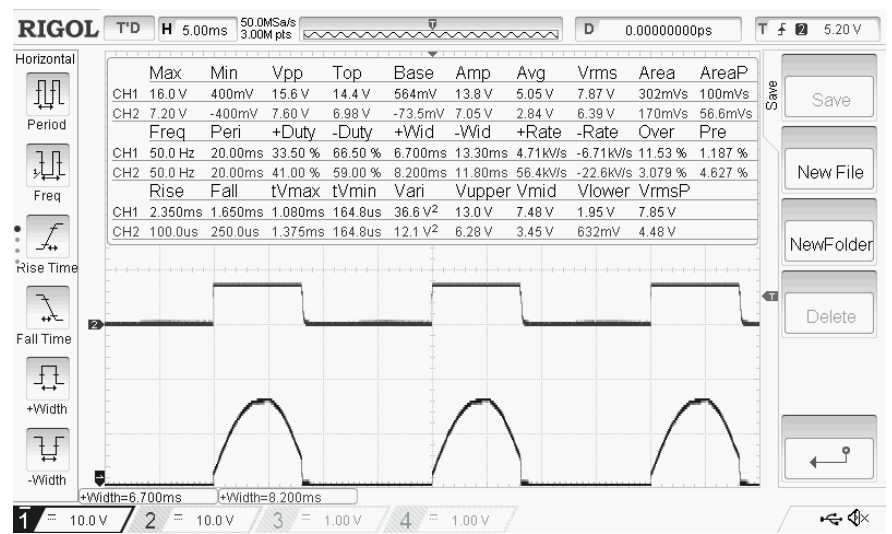

Fig. 43. Output voltage wave shape of IGBT based converter for pulse width $\delta=147.6^{0}$

For this reason, we have consider MATLAB simulation for the THD presented in Table VI. At first pulse width of IGBT is considered $\delta=147.6^{0}$ which corresponds to the firing angle of thyristor, $\alpha=30^{\circ}$ for the same output voltage, $\mathrm{Vdc}=5.03 \mathrm{~V}$. For this pulse width Total Harmonic Distortion (THD) obtained from simulation is $51.87 \%$. The output voltage wave shape and THD is shown in Fig. 43 \& Fig. 44 respectively.

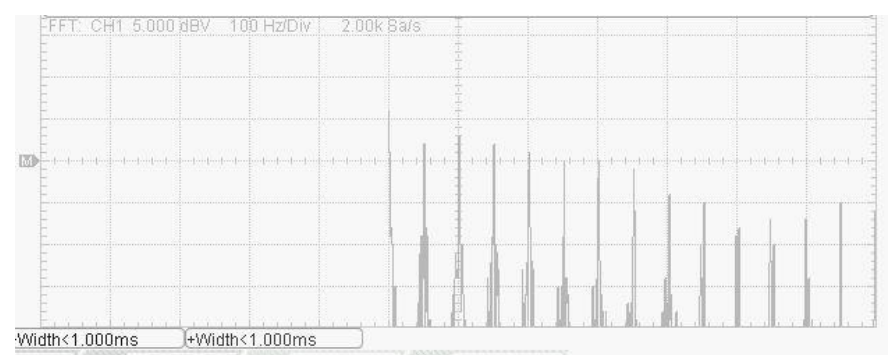

Fig. 44. THD for pulse width $\delta=147.6^{0}$

Next pulse width of IGBT is considered $\delta=113.4^{0}$ which corresponds to the firing angle of thyristor, $\alpha=60^{\circ}$ for the same output voltage, $\mathrm{Vdc}=4.50 \mathrm{~V}$. For this pulse width Total Harmonic Distortion (THD) obtained from simulation is $70.70 \%$. The output voltage wave shape and THD is shown in Fig. 45 \& Fig. 46 respectively.

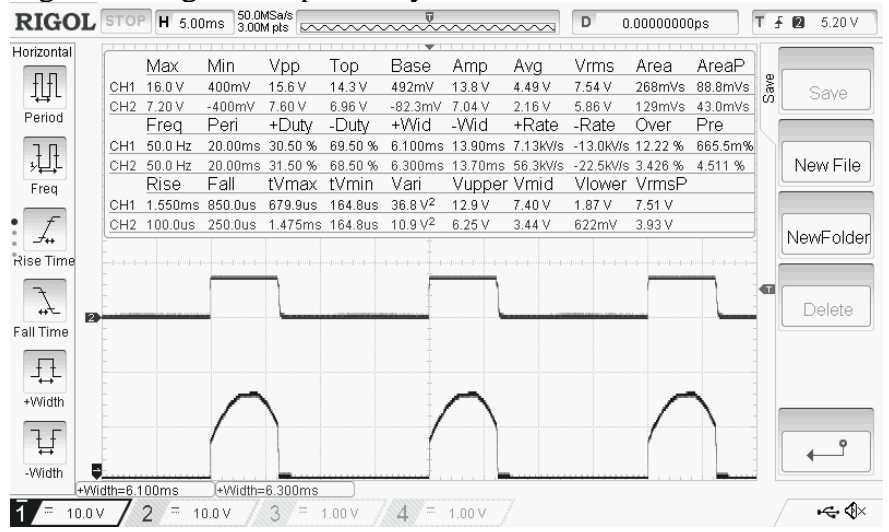

Fig. 45. Output voltage wave shape of IGBT for pulse width $\delta=113.4^{0}$

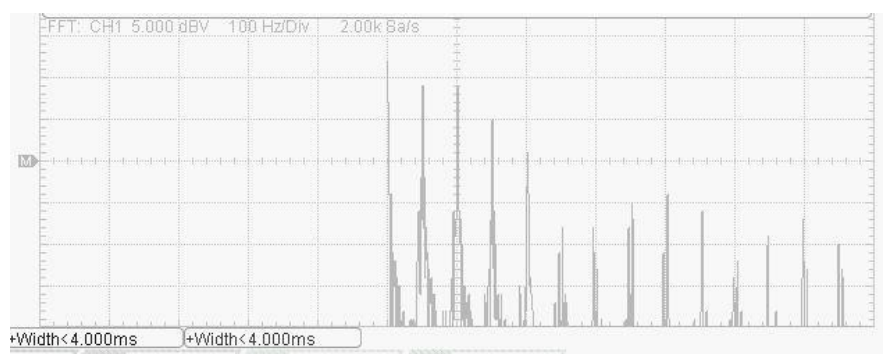

Fig. 46. THD for pulse width $\delta=113.4^{0}$

Similarly pulse width of IGBT is considered $\delta=82.8^{\circ}$ which corresponds to the firing angle of thyristor, $\alpha=90^{\circ}$ for the same output voltage, $\mathrm{Vdc}=3.62 \mathrm{~V}$. For this pulse width Total Harmonic Distortion (THD) obtained from simulation is $98.66 \%$. The output voltage wave shape and THD is shown in Fig. 47 \& Fig. 48 respectively. 


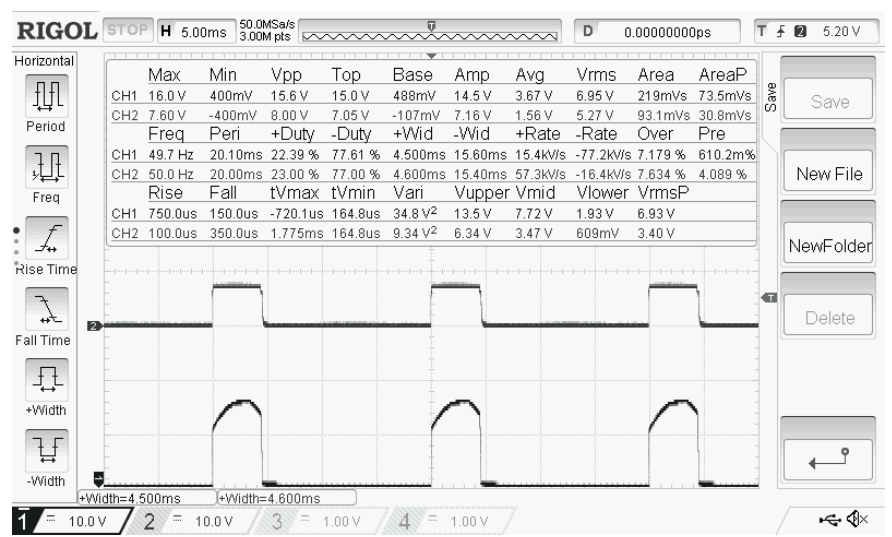

Fig. 47. Output voltage wave shape of IGBT based converter for pulse width $\delta=82.8^{0}$

Again pulse width of IGBT is considered $\delta=64.8^{0}$ which corresponds to the firing angle of thyristor, $\alpha=120^{\circ}$ for the same output voltage, $\mathrm{V}_{\mathrm{dc}}=3.09 \mathrm{~V}$. For this pulse width Total Harmonic Distortion (THD) obtained from simulation is $122.71 \%$. The output voltage wave shape and THD is shown in Fig. 49 \& Fig. 50 respectively.

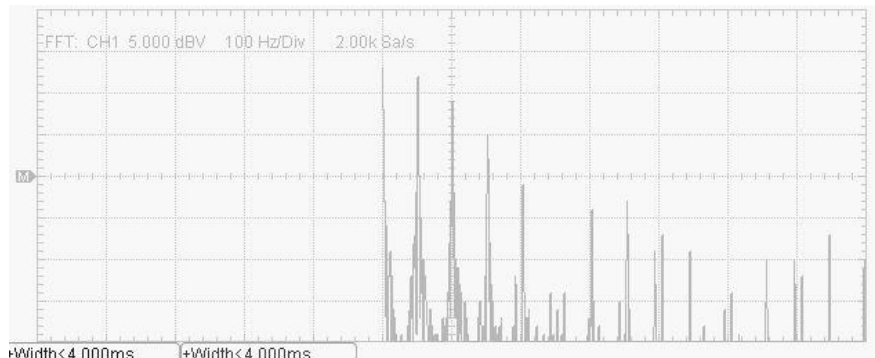

Fig. 48. THD for pulse width $\delta=82.8^{0}$

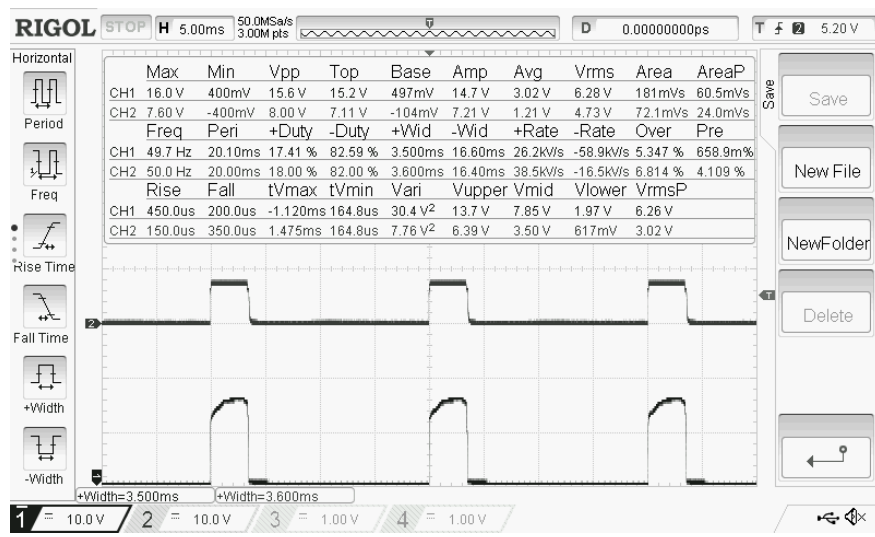

Fig. 49. Output voltage wave shape of IGBT based converter for pulse width $\delta=64.8^{0}$

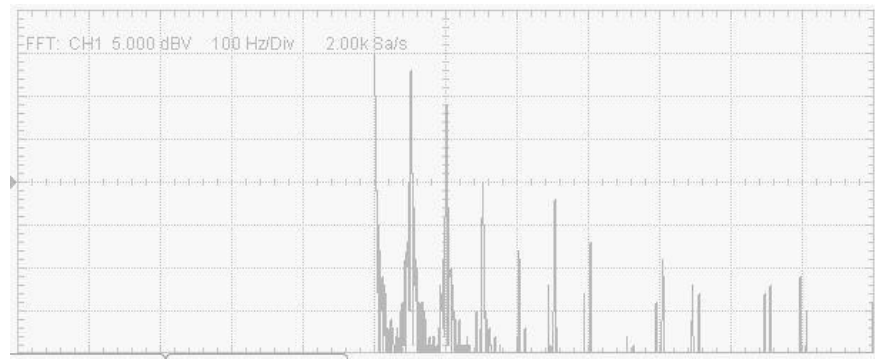

Fig. 50. THD for pulse width $\delta=64.8^{0}$

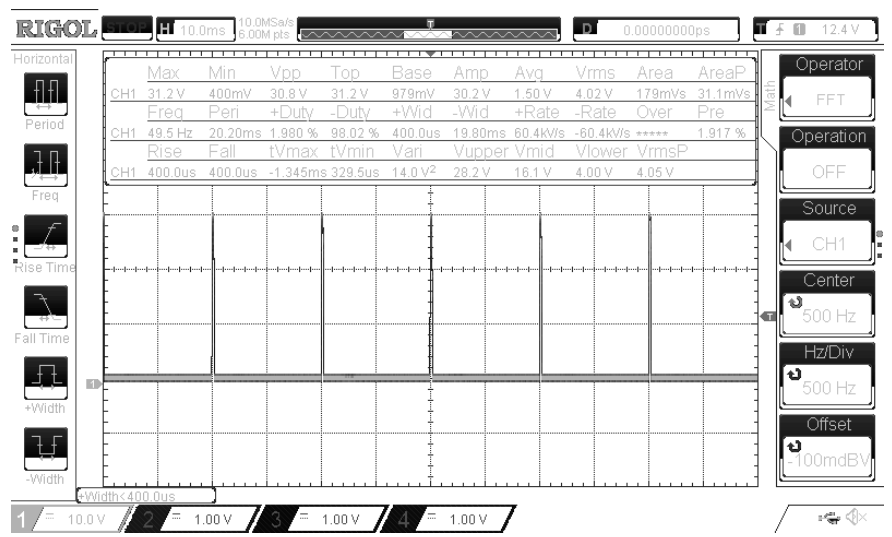

Fig. 51. Output voltage wave shape of IGBT based converter for pulse width $\delta=27.18^{0}$

Finally pulse width of IGBT is considered $\delta=27.18^{0}$ which corresponds to the firing angle of thyristor, $\alpha=150^{\circ}$ for the same output voltage, $\mathrm{V}_{\mathrm{dc}}=1.51 \mathrm{~V}$. For this pulse width Total Harmonic Distortion (THD) obtained from simulation is $223.27 \%$. The output voltage wave shape and THD is shown in Fig. 51 \& Fig. 52 respectively.

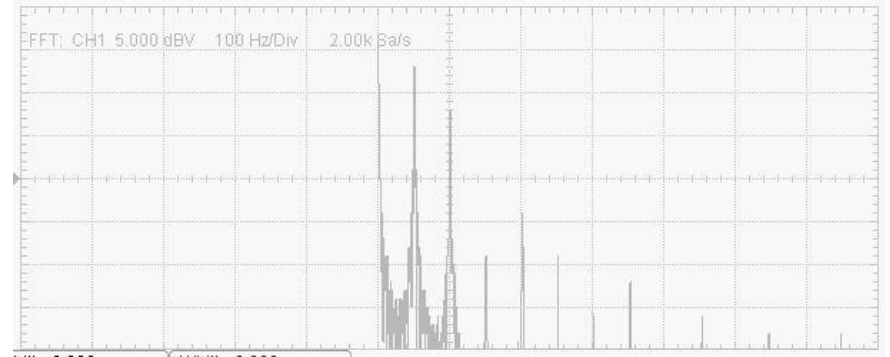

Fig. 52. THD for pulse width $\delta=27.18^{0}$

A summary of the experimental results of THD for thyristor and IGBT is represented in Table VII.

Table VII: Summary of THD for Thyristor and IGBT

\begin{tabular}{|c|c|c|c|c|}
\hline \multicolumn{3}{|c|}{ Thyristor } & \multicolumn{2}{c|}{ IGBT } \\
\hline $\begin{array}{c}\text { Firing } \\
\text { angle, } \\
\text { in } \\
\text { degree }\end{array}$ & $\begin{array}{c}\text { Average } \\
\text { Output } \\
\text { Voltage } \\
\left(V_{\text {dc }}\right) \text { in } \\
\text { Volt }\end{array}$ & THD (\%) & $\begin{array}{c}\text { Pulse } \\
\text { Width, } \delta \\
\text { in } \\
\text { degree }\end{array}$ & THD (\%) \\
\hline $30^{0}$ & 5.03 & 56.21 & $147.6^{0}$ & 60.87 \\
\hline $60^{0}$ & 4.50 & 80.90 & $113.4^{0}$ & 95.70 \\
\hline $90^{0}$ & 3.62 & 115.81 & $82.8^{0}$ & 122.66 \\
\hline $120^{0}$ & 3.09 & 166.96 & $64.8^{0}$ & 210.71 \\
\hline $150^{0}$ & 1.51 & 283.46 & $27.18^{0}$ & 305.27 \\
\hline
\end{tabular}

\section{Conclusion}

In this paper, Thyristor and IGBT based AC-DC power converter has been simulated and tested successfully with resistive load. Experimental findings found symmetrical with simulation result in both cases and THD of IGBT found higher 
than thyristor for the equal output voltage $\left(\mathrm{V}_{\mathrm{dc}}\right)$. It is observed that IGBT based power converter introduces more harmonics in the system, in spite of more symmetrical output voltage wave shape. A micro-controller based control circuit is designed and implemented to generate the firing pulse for both thyristor and IGBT. The control circuit is developed using a multi-winding transformer for the generation of isolated firing pulse.

\section{REFERENCES}

[1] Bimal K. Bose, "Power Electronics and Motor Drives Recent Progress and Prospective", IEEE Transactions on Industrial Electronics, Vol. 56, No. 2, pp. 581-588, February 2009

[2] Muhammad H. Rashid, Power Electronics Circuits, Devices and Applications $6^{\text {th }}$ Edition, Copy right 2009, Prentice Hall, Inc. Upper Saddle River, NJ.

[3] V.K Mehta and R. Mehta, Principles of Electronics (Multicolor Illustrative Edition), Copy Right 2004, 2003, 2002, S. Chand and Company Ltd. NewDelhi.

[4] K. Kant, "Analysis and Design of Cyclo-converter fed Induction motor drive", Ph.D. Thesis, Electrical Engineering Department, IIT Delhi, India 1982.

[5] SangCheol Moon, BingGeun Chun, Gwanbon koo, Jason Guo, Laszlo balogh, "A conduction band control AC-DC Buck converter for a high efficiency and high power density adapter", IEEE Applied Power Electronics Conference and Exposition (APEC), 26-30 March 2017, Tampa, FL, USA.

[6] Shigong Jiang, Weihong Yang, Yunfei Wang and Hongjun Lei, "Research on the classic power supply modes of AC/DC distribution network", Journal of International Council on Electrical Engineering, vol. 8, No. 1, pp. 85-91, November 2018.

[7] Zhihui Chen, Anqi Wang, Changjin Zhang, "A Conduction Angle Controlled Rectifier for a Wound Field Doubly Salient Generator", IEEE International Electric Machines and Drives Conference (IEMDC), 21-24 May 2017, Miami, FL, USA.

[8] Intan Shafinaz Abd. Razak, Raja Intan Zarina Raja Zaki Hashim and Shahril Nizam Mohamed Soid, "A Design of Single Phase Bridge Fullwave Rectifier", Conference on Language, Education, Engineering and Technology, September 2016, Aseania Resort, Langkawi.

[9] Keigo Katagiri, Shota Nakagawa, Kento Kurosawa, Junichi Arai, Yuichi Kado, Keiji Wada, "Power Flow Control of Triple Active Bridge Converter Equipped with AC/DC Converter for Constructing Autonomous Hybrid AC/DC Micro-grid Systems", 43 ${ }^{\text {rd }}$ Annual Conference of The IEEE Industrial Electronics Society (IECON), 29 Oct.1 Nov. 2017, Beijing, China.

[10] Kerim Colak, Erdem Asa, Mariusz Bojarski, Darisuz Czarkowski, "A Novel Common Mode Multiphase Half-wave Semi-synchronous Rectifier for Indcutive Power Transfer Applications", IEEE Transportaion Electrification Conference and Expo (ITEC), 14-17 June 2015, Dearborn, MI, USA.

[11] Sirish Oruganti, Yatin Gilhotra, Neeta Pandey, Rajeshwari Pandey, "New Topologies for OTRA Based Programmable Precision Half-wave and Full-wave Rectifiers", Recent Developments in Control, Automation and Power Engineering (RDCAPE), 26-27 Oct. 2017, Noida, India.

[12] K. Satoh. And M. Yamamoto, "The Present State of the art in high power semiconductor devices," Proc. IEEE, Vol. 89, No. 6, pp. 813-821, Jun. 2001.

[13] Arifur Rahman, Nayeem Ansari, Nazneen Ahmed, Kazi Mujibur Rahman and Md. Zahurul Islam, "Development of a Micro-controller Based AC Voltage Controller with Soft Start Capability", $8^{\text {th }}$ International Conference on Electrical and Computer Engineering, 20-22 December, 2014, Dhaka, Bangladesh.

[14] T.K Chakrobarty, B. Singh and S.P Gupta, "A Microprocessor Based Firing Control Scheme for Three Phase Thyristor Power Converter", Journal of Microcomputer Applications, Vol. 13, pp.361-369, 1990.
[15] B. Singh and P.S Puttswamy, "Microprocessor Based Firing Circuit for a Three Phase Thyristor Converter", Journal of the Institute of Electronic Telecommunications Engineers", May-June 1993, pp. 149-155.

[16] Blaabjerg, F.; Consoli, A.; Ferreira, I.A.; Van Wyk, J.D., "The future of Electronic power processing and conversion", IEEE Transactions on Power Electronics, Vol. 20, Isuue 3, May 2005, pp. 715-720.

[17] Seshadri Gopalan, "Design and Control of Single Phase PWM Rectifier using Two IGBT", International Journal of Advanced Research in Electrical, Electronics and Instrumentation Engineering, Vol. 4, Issue 6, June 2015.

[18] M. Abdullah Al-Amin, Md. Khairul Alam, Md. Moshiur Rahman, "Design and Implementation of Pic16f877A Microcontroller Based Thyristor Firing Controller", International Journal of Engineering Research \& Technology (IJERT), Vol. 2, Issue 12, December-2013.

[19] Zameer Ahmad, S.N. Singh, "Microcontroller Based Advanced Triggering Circuit for Converters/Inverters", International Journal of Engineering Sciences \& Research Technology (IJESRT), pp-88-93, January-2014.

[20] XU Wuxiong, "Design of Thyristor Digital Trigger Circuit Based on Microcontroller Unit", The $1^{\text {st }}$ International Conference on Information Science and Engineering (ICISE2009).

[21] S. Sengupta, S.N. Bhadra and A.K Chattopadhyay, "An Inverter Fed SelfControlled Commutatorless Series Motor with the Field Winding in DC Link", IEEE Transactions on Industry Applications, Vol. 33, No. 4, August 1997.

[22] Tapan Kumar Chakraborty, Shahruk Osman, "A Simple Gate Pulse Generating Circuit for Single Phase Line-Commutated Thyristor Converter", International Journal of Electronics and Electrical Engineering, Vol. 4, No. 5, October 2016.

[23] Richard W. Wall, Herbert L.Hess, "Design and Implementation of a Three Phase SCR Power Converter", Journal of Circuits, Systems and Computers, November 2011.

[24] Qinsong Qian, Weifeng Sun, Taizhi Zhang and Shengli Lu, "A Voltagefed Single stage PFC Full-Bridge Converter with Asymmetric Phase Shifted-Control for Battery Chargers", Journal of Power Electronics, Vol. 17, No. 1, pp. 31-40, January 2017.

[25] H. Jiang, B. Lariviere, D. Lan, J. Zhang, J. Wang, R. Fechter, M. Harrison, and S. Roy, "A Low Switching Frequency AC-DC Boost Converter for Wireless Powered Miniaturized Implants," in Proc. IEE Topical Conference on Biomedical Wireless Technologies, Networks, and Sensing Systems (BioWireleSS), pp. 40-42, January 2014.

[26] Ali M. Eltamaly, PhD, "A New Relation Between Firing Angle of Three Phase SCR Converter And Best Reinjection Current Angle", The Ninth International Middle-East Power Systems Conference, MEPCON'2003, December-16-18,2003.

[27] Shiney.S. Varghese, Sincey George, "Analysis of AC-DC Converter Based on Power Factor and THD", International Journal of Emerging Technology and Advanced Engineering, volume 3, Issue 2, February 2013.

[28] Tanmay Sharma, Dhruvi Dave, Ruchit Soni, "Design and Simulation of Three Phase Controlled Rectifier Using IGBT", International Journal of Application or Innovation in Engineering and Management (IJAIEM), vol. 6, Issue 8, August 2017.

[29] Ahmed Riyaz, Atif Iqbal, Shaikh Moinoddin, Sk. Moin Ahmed, Haitham Abu-Rub, "Comparative Performance Analysis of Thyristor and IGBT Based Induction Motor Soft-starters", International Journal of Engineering, Science and Technology, Vol. 1, No. 1, pp. 90-105, 2009.

[30] Farshid Naseri and Haider Samet, "A Comparison Study of High Power IGBT- Based and Thyristor-Based AC to DC Converters in Medium Power DC Arc Furnace Plants", 9 ${ }^{\text {th }}$ International Conference on Compatibility and Power Electronics (CPE), 24-26 June 2015, Costa da Caparica, Portugal.

[31] Muhammad, Mohammad Shohidul Islam and Ashraful Hoque, "Total Harmonic Distortion Analysis of Front End Current For Diode Rectifier with Sepic PFC", International Journal of Ecosystems and Ecology Science (IJEES), June-2012.

[32] Mohan R. Gangul, G.P Jain, "ATmega328 Microcontroller Based Firing Angle Control of 3 Phase Thyristor Bridge Rectifier Circuit", 
International Journal of Advanced Research in Computer and Communication Engineering, Vol. 4, Issue 7, July 2015.

[33] Md. Saiful Islam, Md. Rifat-Ul-Karim Shovon, Mohd Muinul Haq Mamun, M A G Khan, "Design and Testing of Microcontroller Based Versatile Firing Pulse Generation for Thyristor and Insulated Gate Bipolar Transistor (IGBT)", $2^{\text {nd }}$ International Conference on Innovations in Science, Engineering and Technology, 27-28 October 2018, IIUC, Kumira, Chittagong, Bangladesh.

[34] Mukesh Gupta, Sachin kumar, Vagicharla Karthik, "Design, Fabrication and Testing of Cosine Control Firing Scheme For Single Phase Half Controlled Bridge Rectifier", International Journal of Advanced Research in Electrical, Electronics and Instrumentation Engineering,Vol. 2, Issue 8, August 2013.

[35] R.W. Wall, "Simple Methods for Detecting Zero Crossing", Proceedings of the $29^{\text {th }}$ Annual Conference of the IEEE Industrial Electronics Society, 2-6 Nov, 2003, Roanoke, VA, USA, pp. 2477-2481.

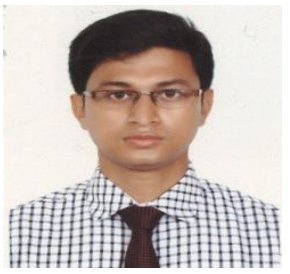

Md. Saiful Islam completed his Bachelor of Science and Master of Science in Electrical \& Electronic Engineering from American International University- Bangladesh in 2015 and 2018. He started his career as an Assistant Service Engineer in 2015 and to till now working for Dana Engineers International Limited (A sister concern of Dana Group) as a Service Engineer. Currently he is working with GE's WAUKEHSA Gas Generator installation, commissioning and troubleshooting in variuos industries in Bangladesh. He commissioned more than $80 \mathrm{MW}$ captive power plant and has $500+$ troubleshoot experience. His research interests are mainly on power electronics specially harmonics mitigation in power converter of distributed power generation, control system, industrial automation, renewable energy and power management system.

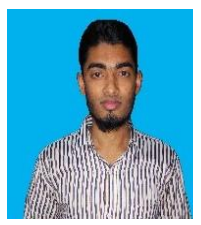

Md. Rifat-Ul-Karim Shovon received his Bachelor degree in Electrical and Electronic Engineering (EEE) from American International University-Bangladesh (AIUB) in 2017. His research interests are in the areas of circuit design, power electronicns, bio-medical instrument design, VLSI design.

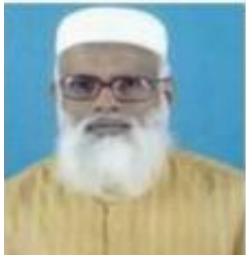

Dr. Mohammad Abdul Goffar Khan received his Bachelor degree in Electrical and Electronic Engineering from Rajshahi University of Engineering \& Technology (RUET), former Rajshahi Engineering College in 1983 and MSc. in Electrical and Electronic Engineering from Bangladesh University of Engineering and Technology (BUET) in 1987. He received his $\mathrm{Ph} . \mathrm{D}$. degree from Indian Institute of Technology, Kanpur (IITK), India in 1997. He started his carrier as a lecturer in RUET and became Professor there in 2002. Presently he is working as a research professor in EEE department at American International University- Bangladesh (AIUB). His research field includes power electronics, renewable energy, advanced optical fibers etc. He has published more than 80 research papers in different journals and conference proceedings. $\mathrm{He}$ is an active member of different professional organizations. He was elected vice Chair of IEEE Bangladesh section for three consecutive years of 2015, 2016 and 2017. 
